\title{
TLR2 Elicits IL-17-Mediated RANKL Expression, IL-17, and OPG Production in Neutrophils from Arthritic Mice
}

\author{
Viktoriya Milanova, Nina Ivanovska, and Petya Dimitrova \\ Department of Immunology, Institute of Microbiology, Bulgarian Academy of Sciences, 26 Georgi Bonchev street, 1113 Sofia, Bulgaria \\ Correspondence should be addressed to Petya Dimitrova; petya_dimitrova@web.de
}

Received 24 October 2013; Accepted 6 January 2014; Published 16 March 2014

Academic Editor: Frédérique Ponchel

Copyright (C) 2014 Viktoriya Milanova et al. This is an open access article distributed under the Creative Commons Attribution License, which permits unrestricted use, distribution, and reproduction in any medium, provided the original work is properly cited.

\begin{abstract}
We investigated the ability of neutrophils to express receptor activator of nuclear factor kappa-B ligand (RANKL), to secrete osteoprotegerin (OPG), and to produce IL-17. Arthritis was induced by intra-articular injection of zymosan, a ligand for Tolllike receptor 2 (TLR2). Frequencies of neutrophils in bone marrow (BM), blood and synovial fluid (SF), receptor expression, and cytokine production were evaluated by flow cytometry. 1A8 antibody (1A8 Ab) was used to deplete neutrophils in zymosan-injected SCID mice. IL-17, RANKL, and OPG amounts in SF, serum, or cell cultures were determined by ELISA. The development of arthritis was associated with increased secretion of IL-17, RANKL, and OPG in serum and SF, elevated frequencies of Ly6G CD11b $^{+}$cells in BM, blood, and SF and upregulated RANKL expression. Both IL-17 and OPG were absent in serum and SF after neutrophil depletion; therefore we assume that they were released by neutrophils. In vitro blood $\mathrm{Ly}_{6 \mathrm{G}}^{+} \mathrm{CD}_{11 \mathrm{~b}}^{+}$cells from arthritic mice produced spontaneously IL-17, IFN- $\gamma$, and OPG and expressed RANKL. This phenotype was sustained by IL-17. TLR2 engagement increased IL-17 and IFN- $\gamma$ production, potentiated IL-17-mediated RANKL expression, and inhibited OPG secretion. We conclude that TLR2 regulates the destructive potential of neutrophils and its targeting might limit joint alterations in arthritis.
\end{abstract}

\section{Introduction}

Neutrophils are the most abundant cells in SF at the initial phase of rheumatoid arthritis (RA). They deliver signals or/and release factors regulating the functions of synovial fibroblasts, chondrocytes, osteoclasts, and other inflammatory cells like monocytes, $\mathrm{T}$ and $\mathrm{B}$ cells, dendritic cells, and NK cells. Neutrophils from RA patients are functionally different from those of healthy donors (reviewed by [1]). They have an active NF- $\kappa \mathrm{B}$ signaling pathway and produce considerable amounts of reactive oxygen species and tumor necrosis factor (TNF)- $\alpha$ [1]. Their cytoplasm is enriched with granules containing proteases, phospholipases, defensins, and myeloperoxidase (just before being reviewed in [2]). The release of all these factors in SF induces collagen and proteoglycan depletion, receptor shedding, cytokines degrading, and activation of cytokine precursors. Neutrophils from RA patients have also delayed apoptosis and are susceptible to stimulation via TLRs and receptors for complement fragments, growth factors, and cytokines (reviewed by [3]).
Among the members of the Toll-like receptors, family is TLR2. The receptor interacts with microbial lipopeptides such as peptidoglycan from gram-positive bacteria, lipoarabinomannan from mycobacteria, and zymosan (ZY) from yeast cell wall. TLR2 has an extracellular domain with leucine-rich repeats and a conservative intracellular Toll/IL1 receptor (TIR) domain. TLR2 forms homodimers or heterodimers with TLR1 or TLR6 [4]. Its downstream pathways involve myeloid differentiation factor 88 (MyD88), c-Jun Nterminal kinase, NF- $\kappa \mathrm{B}$, and phosphatidylinositol 3-kinase (PI3K), which promotes NF- $\kappa \mathrm{B}$-dependent transcription too (reviewed by [5]). Various studies have shown the role of TLR2 signaling for the development of arthritis (reviewed by [6]). Among them are investigations on TLR2-deficient mice describing a direct suppression of neutrophils function in these animals and better outcome from arthritis $[7,8]$.

IL-17 is characteristic for the early stage of arthritis and plays a role in various inflammatory and autoimmune pathologies [9-11]. Elevated IL-17 mRNA expression in SF can predict the progression of joint damage and occurs before the 
disease onset $[12,13]$. The overexpression of IL-17 promotes the development of collagen-induced arthritis, while IL-17 neutralization inhibits bone erosion and cartilage damage $[14,15]$. IL-17 interferes with RANKL signaling pathway, osteoclastogenesis and maintains matrix turnover and cartilage destruction, especially in the presence of TNF- $\alpha[16$, 17]. The cytokine promotes not only joint inflammation but also a bone-protective potential of neutrophils in periodontal disease [18].

Neutrophils from RA patients express RANKL and secrete a decoy RANKL receptor, OPG [19]. We have found abrogated RANKL expression on neutrophils that contributes to better outcome from collagen-antibody-induced arthritis in properdin-deficient mice [20]. In a model of collagenaseinduced osteoarthritis glucosamine inhibits bone destruction and decreases the number of RANKL-bearing neutrophils in SF [21]. Our previous studies involving patients with osteoarthritis show altered TNF- $\alpha$ production in response to TLR2 stimulation and elevated TLR2 and RANKL expression on blood neutrophils $[22,23]$. In the present work we investigate the bone-destructive activity of $\mathrm{Ly}_{6 \mathrm{G}}{ }^{+} \mathrm{CD} 1 \mathrm{~b}^{+}$cells in TLR2 ligand driven arthritis. To confirm that neutrophils directly participate in bone resorption monoclonal 1A8 $\mathrm{Ab}$ recognizing that $\mathrm{Ly} 6 \mathrm{G}$ was administrated to zymosaninjected SCID mice. $\mathrm{Ly}_{6 \mathrm{G}}{ }^{+} \mathrm{CD}_{11 b^{+}}$cells were depleted in circulation and we measured the concentrations of IL-17, RANKL, and OPG in SF and serum. We examined IL-17 and IFN- $\gamma$ production of blood neutrophils by flow cytometry and we evaluated the effect of IL-17 and TLR2 stimulation on cytokine production, RANKL expression, and OPG secretion in these cell cultures.

\section{Materials and Methods}

2.1. Animals. All experiments were approved by the Animal Care Committee at the Institute of Microbiology, Sofia, in accordance with the National and European Guidelines. $\mathrm{BALB} / \mathrm{c}$ and SCID (CB17) mice were purchased from the Charles River Laboratories (USA), kept under standard conditions of a 12-12 hours light-dark cycle, and fed with a laboratory diet and water ad libitum. Mice (weigh 20$22 \mathrm{~g}$ ) were anesthetized by intraperitoneal injection (i.p.) of sodium pentobarbital (50 mg/kg; Sigma-Aldrich, Munich, Germany) supplemented with buprenorphine hydrochloride analgetic (0.1 mg/kg; Sigma-Aldrich).

2.2. Arthritis. BALB/c mice were injected intra-articularly (i.a.) at ankles or knees with $10 \mu \mathrm{L}$ of zymosan suspension $(20 \mathrm{mg} / \mathrm{mL}$; Sigma-Aldrich) or $10 \mu \mathrm{L}$ of endotoxin-free phosphate-buffered saline (PBS; control group). To deplete neutrophils in SCID mice monoclonal 1A8, Ab (endotoxin free, $100 \mu \mathrm{g}$ in $200 \mu \mathrm{L}$ per mouse; Biolegend, London, UK) was administered i.p. at days $-2,+2$, and +4 . At day 0 SCID mice were injected i.a. with PBS (PBS + Ab group) or zymosan $(\mathrm{ZY}+\mathrm{Ab}$ group). The development of disease for 7 days was compared to untreated PBS- (PBS group) or zymosan(ZY group) injected SCID mice. To monitor cell depletion Ly6 $\mathrm{G}^{+} \mathrm{CD}_{11 b^{+}}$cell, frequencies were assessed in BM at days $-2,+2$, and +4 .
2.3. Histology. At day 7 of arthritis, ankle or knee joints were dissected, fixed in $10 \%$ paraformaldehyde/PBS, decalcified in $5 \%$ nitric acid for 1 week, dehydrated, embedded in paraffin, cut, and stained with hematoxylin and eosin (H\&E) or Safranin O [24]. The degree of injury was graded by a three score system applied for cell infiltration and proteoglycan loss (score 0-no abnormality; score 3-severe abnormalities) and determined by two independent observers using light microscopy (Leica Microsystems, Wetzlar, Germany). Cartilage erosion was expressed as the percentage of impaired cartilage from the total cartilage surface and was determined after photo capturing by a DS-Ril Nikon camera (Nikon Instruments Europe, Amstelveen, The Netherlands) and image analyses by ImageJ 1.42 software (Research Services Branch, NIH, Bethesda, MD, USA).

2.4. ELISA Assay. SF was harvested from ankles or knees by lavage with $25 \mu \mathrm{L}$ of PBS containing $1 \mathrm{mM}$ EDTA (SigmaAldrich). Serum was obtained after centrifugation of collected blood. RANKL, OPG, and IL-17 were quantified in SF, serum, or culture supernatants by ELISA kits from Abcam (Cambridge, UK; detection limit $<4 \mathrm{pg} / \mathrm{mL}$ and of $<1 \mathrm{pg} / \mathrm{mL}$, resp.) and from Biolegend (London, UK; detection limit < $8 \mathrm{pg} / \mathrm{mL}$ ). The samples were assayed in triplicate. The concentrations of RANKL, OPG, and IL-17 were calculated from a standard curve of the respective recombinant mouse protein using Gen5 Data Analysis Software (BioTek Instruments, Bad Friedrichshall, Germany).

2.5. Cell Isolation and Phenotype. Synovial cells were isolated by centrifugation of SFs. Peripheral cells were obtained from heparinized blood after Histopaque (Sigma-Aldrich) density gradient centrifugation. BM cells were collected from the tibia and femur. Exclusion dye staining with $0.05 \%$ Trypan blue showed more than $95 \%$ viable cells in isolated populations. After washing, cells were resuspended at $1 \times 10^{5} / \mathrm{mL}$ in $2 \% \mathrm{FCS} / \mathrm{PBS}$ and incubated with Abs against mouse Ly6G (clone 1A8; Biolegend), CD11b (clone M1-70; Biolegend), and CD69 (clone H1.2F3; BD Pharmingen, BD Biosciences, Heidelberg, Germany). RANKL expression was evaluated after incubation with biotinylated $\mathrm{Ab}$ against mouse RANKL (clone IK22/5; Biolegend) or biotinylated rat IgG2a (isotype control; Biolegend) followed by avidin-fluorescein isothiocyanate (FITC) staining ( $4 \mu \mathrm{g} /$ sample, R\&D Systems, Wiesbaden-Nordenstadt, Germany) [21]. The samples were analyzed with flow cytometer (BD LSR II) using BD FACSDiva v6.1.2 Software (Becton Dickinson GmbH, San Jose, CA, USA).

2.6. Purification and Activation of Blood Neutrophils. Neutrophils were purified from heparinized blood as described previously [25]. Cell population consists of $>95 \%$ viable cells and of $89-90 \%$ positive cells for Ly6G and CD11b. Neutrophils were resuspended at concentration of $1 \times 10^{6} / \mathrm{mL}$ in sterile complete RPMI-1640 medium (Biowhittaker; Lonza, Basel, Switzerland) containing 10\% FCS, 2 mM Lglutamine, $100 \mathrm{U} / \mathrm{mL}$ penicillin, $100 \mu \mathrm{g} / \mathrm{mL}$ streptomycin (all from Sigma-Aldrich), and granulocyte-macrophage colonystimulating factor (GM-CSF; $50 \mathrm{ng} / \mathrm{mL}$; PeproTech EC, 
London, UK). The cells were stimulated with zymosan $(20 \mu \mathrm{g} / \mathrm{mL}$; Sigma-Aldrich) in the absence or presence of IL-17 (40 ng/mL; Abcam). After 24 hours, $37^{\circ} \mathrm{C}$, cells were harvested, washed, and analyzed for RANKL expression and intracellular cytokine production. OPG concentrations in culture supernatants were also measured.

2.7. Intracellular Flow Cytometry. Neutrophils or synovial cells $\left(1 \times 10^{6} / \mathrm{mL}\right)$ were stimulated with phorbol myristate acetate (PMA; $10 \mathrm{ng} / \mathrm{mL}$; Sigma-Aldrich) and ionomycin ( $2 \mu \mathrm{M}$; Sigma-Aldrich) in the presence of brefeldin (GolgiStop, BD Pharmingen) for 4 hours. Cells were harvested, washed, stained with antibody against Ly6G, then fixed, and permeabilized (BD Cytofix/Cytoperm kit, BD Biosciences). After incubation with Abs against IL-17 (clone TC11-18H10), IFN- $\gamma$ (clone XMG1.2), and appropriate isotype controls (all from BD Pharmingen), cells were subjected to flow cytometry analysis.

2.8. Immunoblotting. Blood neutrophils $\left(1 \times 10^{6} / \mathrm{mL}\right)$ were stimulated with zymosan $(20 \mu \mathrm{g} / \mathrm{mL})$ and GM-CSF $(50 \mathrm{ng} /$ $\mathrm{mL}$ ) for $10 \mathrm{~min}, 37^{\circ} \mathrm{C}$ in the absence or presence of IL-17 $(40 \mathrm{ng} / \mathrm{mL})$. Cells were washed with ice-cold PBS and lysed for $15 \mathrm{~min}$ on ice with buffer containing $10 \mathrm{mM}$ HEPES ( $\mathrm{pH}$ 7.9), $1.5 \mathrm{mM} \mathrm{MgCl}, 10 \mathrm{mM} \mathrm{KCl,} 0.5 \mathrm{mM}$ DTT, $0.5 \% \mathrm{NP}-$ 40, $0.5 \mathrm{mM}$ phenylmethanesulfonylfluoride (PMSF), $1 \mathrm{mM}$ $\mathrm{Na}_{3} \mathrm{VO}_{4}, 5 \mathrm{mM} \mathrm{NaF}$, and $1 \mu \mathrm{g} / \mathrm{mL}$ protein kinase inhibitor cocktail (all from Sigma-Aldrich). Cell lysates were centrifuged at $13000 \mathrm{~g}, 4^{\circ} \mathrm{C}$. Supernatants were discarded, and cell pellets were resuspended and incubated for $1 \mathrm{~h}$ on ice in buffer containing $20 \mathrm{mM}$ HEPES ( $\mathrm{pH} 7.9$ ), $1.5 \mathrm{mM} \mathrm{MgCl}_{2}$, $420 \mathrm{mM} \mathrm{NaCl}, 0.2 \mathrm{mM}$ EDTA, 25\% v/v glycerol, $0.5 \mathrm{mM}$ PMSF, and $1 \mu \mathrm{g} / \mathrm{mL}$ protein kinase inhibitor cocktail and centrifuged at $13000 \mathrm{~g}, 4^{\circ} \mathrm{C}$. Cell lysates $(20 \mu \mathrm{g} /$ line $)$ were separated by $10 \%$ SDS/PAGE gel electrophoresis and transferred onto nitrocellulose membrane (Thermo Scientific, Rockford, IL, USA). After blocking with 5\% BSA/PBS buffer, the membranes were probed overnight with Abs against methyl histone H3 (mono methyl K9, 1:500 diluted, Abcam) or lamin, nuclear lamina protein (clone C-20, Santa-Cruz Biotech, Heidelberg, Germany). After washing, immunoblots were incubated with peroxidase-conjugated anti-rabbit IgG $\left(\mathrm{Fab}_{2}\right)$ antibody (1:1000 diluted; Abcam) and then developed using a chemiluminescent substrate kit (Sigma-Aldrich). Protein band density was analyzed by ImageJ 1.42 software (Research Services Branch, NIH, Bethesda, MD, USA). In each sample H3K9 lines were normalized to that of lamin and presented in units.

2.9. Statistical Analysis. Statistical analysis was accomplished by InStat3.0 and GraphicPad Prism 5.0 software (GraphPad Software, La Jolla, CA, USA). Data were expressed as mean \pm SEM. Kruskal-Wallis and Mann-Whitney $U$-tests were performed to compare the histological scores and the percentages of cartilage erosion between groups and to calculate statistical significance of the differences. For other data, the differences in the mean values between groups were analyzed with the two-tailed Student's $t$-test. Differences were considered significant when $P<0.05$.

\section{Results}

3.1. Neutrophils Depletion in Arthritic Mice Decreases IL17 and OPG Amounts in Synovial Fluid and Serum. TLR2driven arthritis was induced by i.a. injection of zymosan into BALB/c mice. Histological evaluation of H\&E and Safranin $\mathrm{O}$ stained joint sections showed cell infiltration, cartilage erosion, and proteoglycan loss at day 7 of arthritis induction (Figures 1(a) and 1(b)). The amount of IL-17 raised in SF and serum of arthritic mice (Figure 1(c)). Cells accumulated in SF (Figure 1(d)). We observed increased frequencies of ${\text { Ly } 6 G^{+}}^{+} \mathrm{CD}_{11 b^{+}}$neutrophils in SF and blood (Figure $1(\mathrm{~d})$ ). CD69, characteristic for active and primed cell state, was upregulated on SF and blood $\mathrm{Ly}_{6} \mathrm{G}^{+}$cells from zymosaninjected mice (Figure 1(e)).

Next we designed an experiment for neutrophil depletion by specific $1 \mathrm{~A} 8 \mathrm{Ab}$. SCID mice were used in these settings because they lack mature $\mathrm{T}$ and $\mathrm{B}$ cells but have intact innate immunity. The mice were treated with monoclonal $1 \mathrm{~A} 8 \mathrm{Ab}$ at days $-2,+2$, and +4 of zymosan injection (Figure $2(\mathrm{a})$ ).

This schedule was chosen because TLR2 ligand induced granulopoiesis even after initial $1 \mathrm{~A} 8 \mathrm{Ab}$ administration (Figure 2(a), day +2 ) and the loss of $\mathrm{Ly}_{6 \mathrm{G}}{ }^{+} \mathrm{CD}_{11 \mathrm{~b}}{ }^{+}$cells in BM granulocyte subset (Figure 2(a), day -2 ). Thus cell depletion was maintained by additional $\mathrm{Ab}$ treatments at days +2 and +4 (Figure 2(a)). At day 7 of arthritis and 3 days after the last administration of $1 \mathrm{~A} 8 \mathrm{Ab}$, the neutrophils partially recovered in BM but were still absent from the circulation and SF (Figure 2(b)). Histological evaluation of the joint sections at day 7 showed a considerable decrease in cell infiltration, PG loss, and cartilage erosion in $1 \mathrm{~A} 8$ Ab-treated ZY group (Figure 2(c)). Disease improvement was associated with diminished amounts of RANKL in serum and SF (Figure 2(d)). The administration of $1 \mathrm{~A} 8 \mathrm{Ab}$ completely inhibited TLR2 ligand-induced production of IL-17 (Figure 2(e)) and OPG (Figure 2(f)) suggesting that $\mathrm{Ly} 6 \mathrm{G}^{+} \mathrm{CD} 11 \mathrm{~b}^{+}$neutrophils might be the source of both mediators in circulation and SF. This notion, however, posed more questions about the ability of $\mathrm{Ly} 6 \mathrm{G}^{+} \mathrm{CD} 11 \mathrm{~b}^{+}$ neutrophils to produce IL-17 and OPG in response to TLR2 stimulation.

\subsection{Altered IL-17 and IFN- $\gamma$ Production of Blood Neutrophils} from Arthritic Mice in Response to TLR2 Stimulation In Vitro. Neutrophils in circulation of arthritic mice can be a source of proinflammatory cytokines as they were activated and/or primed and expressed the early activation marker CD69 (see Figure 1(e)). We purified neutrophils from blood of control (PBS-injected) and arthritic BALB/c mice. The cells were cultured in the presence of GM-CSF, a factor sustaining cell survival. Ly6 $\mathrm{G}^{+} \mathrm{CD} 1 \mathrm{~b}^{+}$cells were stimulated in vitro with TLR2 ligand and/or IL-17 for 24 hours. The intracellular production of IL-17 and IFN- $\gamma$ was evaluated by flow cytometry (Figures 3(a) and 3(b)).

$\mathrm{Ly}_{6 \mathrm{G}}{ }^{+} \mathrm{CD}_{11 b^{+}}$cells from nonarthritic mice were IFN$\gamma^{-} / \mathrm{IL}-17^{-}$, IL-17 induced autocrine IL-17 protein expression and IFN- $\gamma$ production in control neutrophils (representative dot-plots and graphs, Figure 3(a)). Zymosan was able to prime the control neutrophils for IFN- $\gamma$ synthesis but it failed 


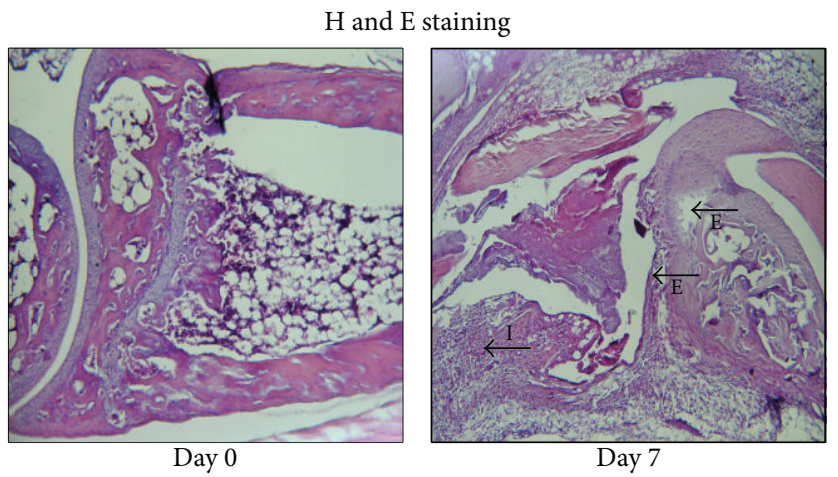

(a)
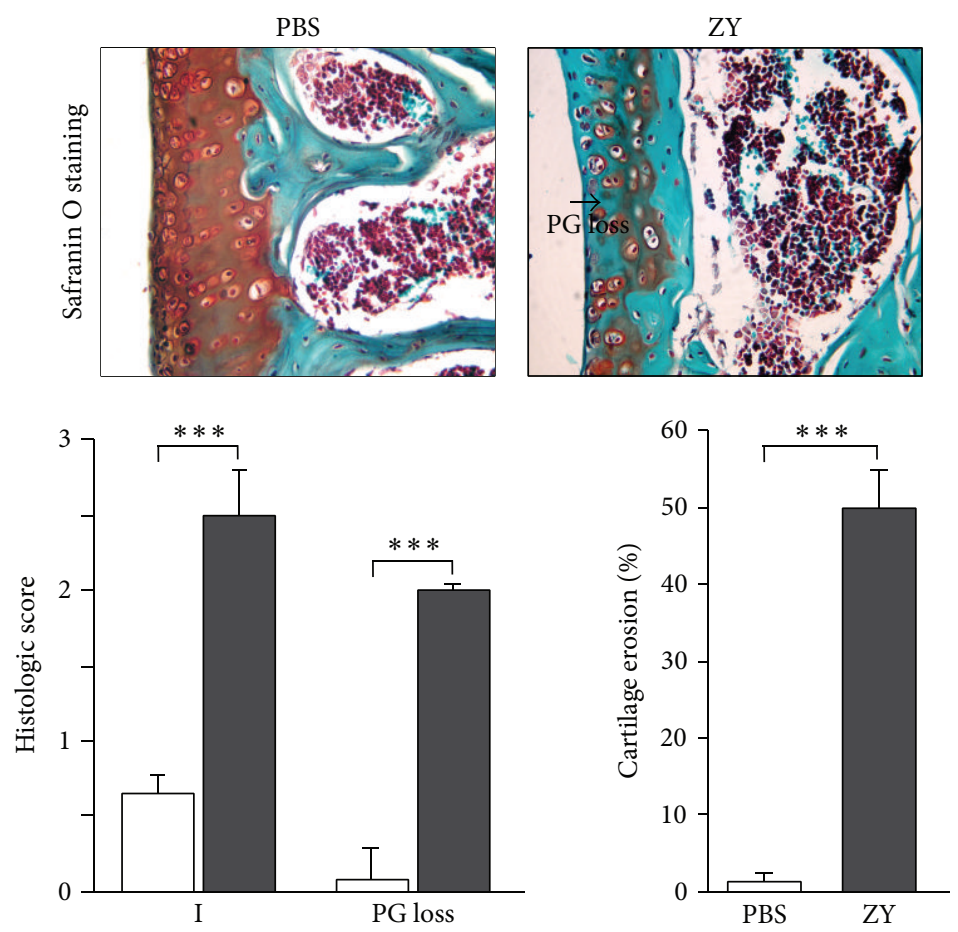

$\square$ PBS

$\square \mathrm{ZY}$

(b)
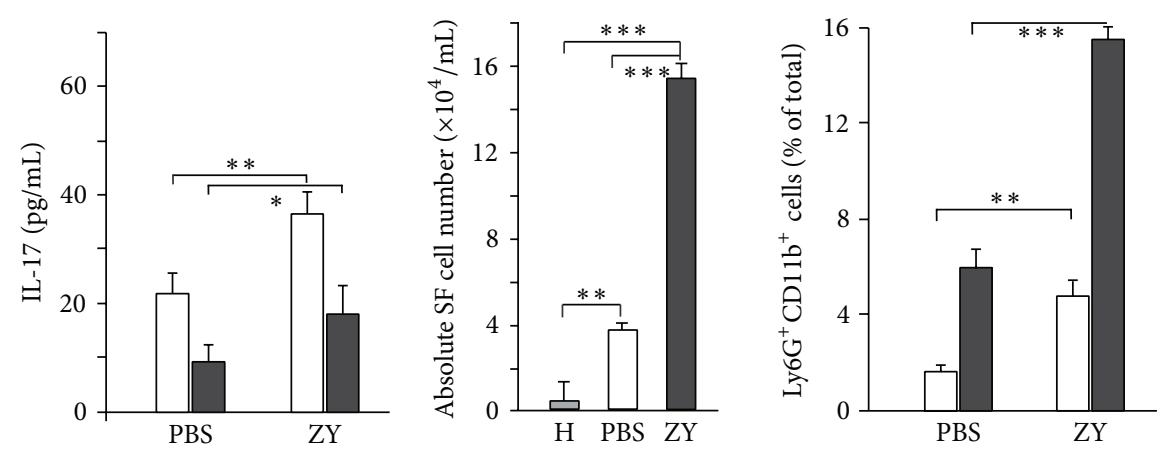

$\square$ SF

$\square \mathrm{SF}$

$\square \mathrm{SF}$

$\square$ Blood

$\square$ Blood

$\square$ Blood

(c)

(d)

Figure 1: Continued. 


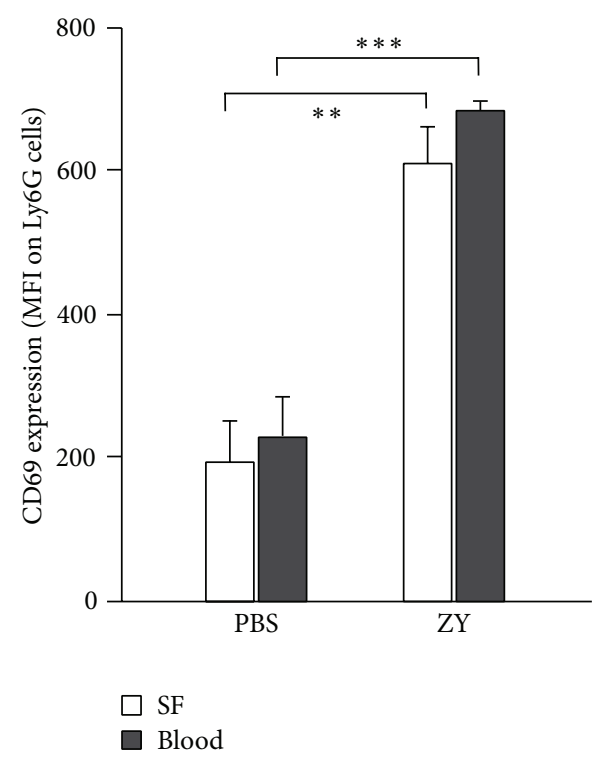

(e)

FIGURE 1: Arthritis induced by intra-articular TLR2 ligand (zymosan; ZY) injection into BALB/c mice. (a) Representative photomicrographs of hematoxylin and eosin (H\&E) stained ankle sections show cell infiltration (arrow, I) and cartilage erosion (arrows, E) at day 7 of zymosan injection (200 $\mu \mathrm{g} / 10 \mu \mathrm{L}$ per ankle) (magnification 40x). (b) Photomicrographs of Safranin O stained sections (magnification 100x) and scores for cell infiltration (I), proteoglycan loss (PG loss), and cartilage erosion indicates severe joint injury in zymosan-injected mice (ZY) in comparison to PBS-injected group (PBS). Values are the mean \pm SEM (10 sections/mouse; $n=10$ mice/group; 5 experiments). ${ }^{* * *} P<0.001$, Kruskal-Wallis and Mann-Whitney $U$-test. (c) Increased IL-17 amounts in SF and serum of mice with arthritis (day 7). Bars show the mean \pm SEM ( $n=5$ mice/group; 3 experiments). ${ }^{*} P<0.05 ;{ }^{* *} P<0.01$, Student's $t$-test. (d) Cells accumulate in SF and frequencies of Ly6G ${ }^{+} \mathrm{CD} 11 \mathrm{~b}^{+}$ cells increase in SF and blood at day 7 of arthritis. Values are the mean $\pm \operatorname{SEM}\left(n=10\right.$ mice/group; 5 experiments). ${ }^{* *} P<0.01 ;{ }^{* * *} P<0.001$ versus healthy $(\mathrm{H})$ or versus PBS-injected groups (PBS), Student's $t$-test. (e) Blood and SF Ly6G cells upregulate surface CD69 at day 7 of arthritis. Values are the mean \pm SEM ( $n=5$ mice/group; 3 experiments). ${ }^{* *} P<0.01$; ${ }^{* * *} P<0.001$, Student's $t$-test. MFI: mean fluorescence intensity.

to initiate IL-17 production even in the presence of exogenous IL-17 (Figure 3(a)).

Neutrophils from arthritic mice produced IL-17 and IFN- $\gamma$ spontaneously unlike the cells from the control group (Figure $3(\mathrm{~b})$ ). We detected around $4 \% \mathrm{IL}-17^{+}$cells and near $2 \%$ IFN- $\gamma^{+}$cells (dot-plot histograms and graphs, Figure $3(\mathrm{~b}))$. IL- $17^{+}$but not IFN- $\gamma^{+}$neutrophils were influenced by exogenous IL-17 in the cultures (Figure 3(b)). Zymosan provided stronger signal for IL-17 synthesis and amplified the generation of $\mathrm{IL}-17^{+}$cells more efficiently (Figure 3(b)). However, TLR2 enhanced the frequencies of IFN $-\gamma^{+}$neutrophils, but it failed to potentiate further IFN$\gamma$ synthesis in the presence of IL-17. Together our data demonstrated (i) that blood neutrophils from arthritic mice have an increased potential to produce IL-17 and IFN- $\gamma$ in comparison with control cells and (ii) that TLR2 is necessary to be stimulus (signal) for enhanced generation of IL- $17^{+}$and IFN $-\gamma^{+}$neutrophils in cultures from arthritic group.

Neutrophil function can be regulated by epigenetic mechanisms involving methylation and acetylation of histones. We evaluated by immunoblot the levels of monomethylated $\mathrm{H} 3 \mathrm{~K} 9$ in blood neutrophils activated with zymosan and/or IL-17. Methylated H3K9 was undetectable in the nuclear extracts of nonstimulated $\mathrm{Ly}_{6} \mathrm{G}^{+} \mathrm{CD} 1 \mathrm{~b}^{+}$cells from control mice and present in those from arthritic group (Figure 4).
IL-17 elevated the levels of the methylated protein in neutrophils from control but not from arthritic mice (Figure 4). These data suggest that TRL2 and IL-17 pathways might have an important impact in the epigenetic control of neutrophil functions and cytokine production. In the context of our studies they could crosstalk and compete to regulate neutrophils activities in health and disease.

3.3. TLR2 Ligand and IL-17 Regulate RANKL Expression and OPG Secretion by Neutrophils. At day 7 of arthritis induction, the level of IL-17 in serum was elevated (Figure 1(c)) and the frequencies of IL- $17^{+}$neutrophils were enhanced in the circulation (Figure 3(b)). In order to study how this altered IL-17 production influences the destructive potential of neutrophils, we analyzed the expression of RANKL, a molecule directly involved in bone erosion and resorption. Blood $\mathrm{Ly}_{6 \mathrm{G}}{ }^{+} \mathrm{CD} 11 b^{+}$cells from nonarthritic mice did not express RANKL (histograms, Figure 5(a)). Exogenous IL-17 induced RANKL expression (histograms, Figure 5(a)) and increased the frequencies of $\mathrm{RANKL}^{+}$neutrophils in the control group (graph, Figure 5(b)). However, TLR2 ligand failed to trigger RANKL expression on neutrophils from control mice even in the presence of IL-17 (histograms, Figure 5(a) and graph, Figure 5(b)). 


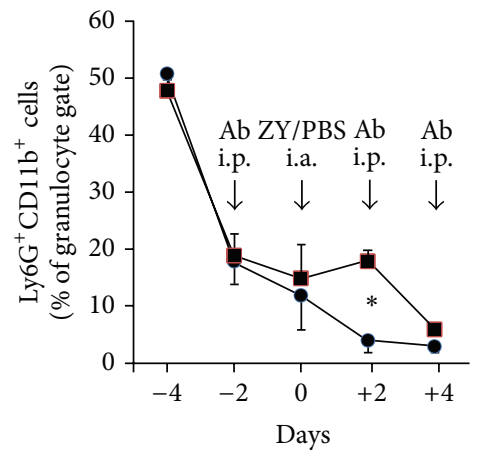

ZY

(a)

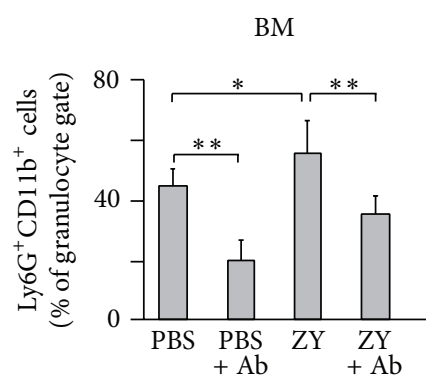

SF

Blood
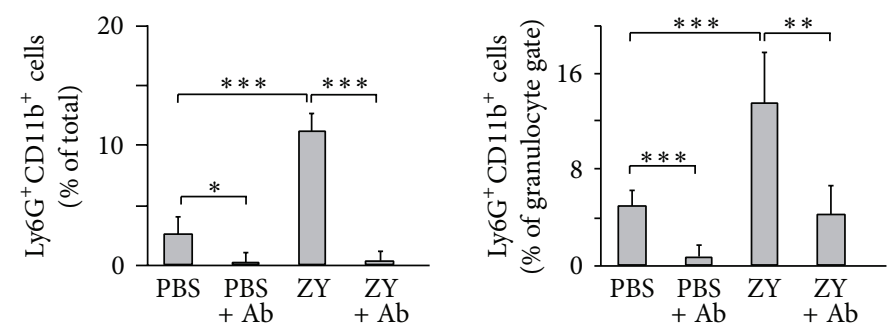

(b)
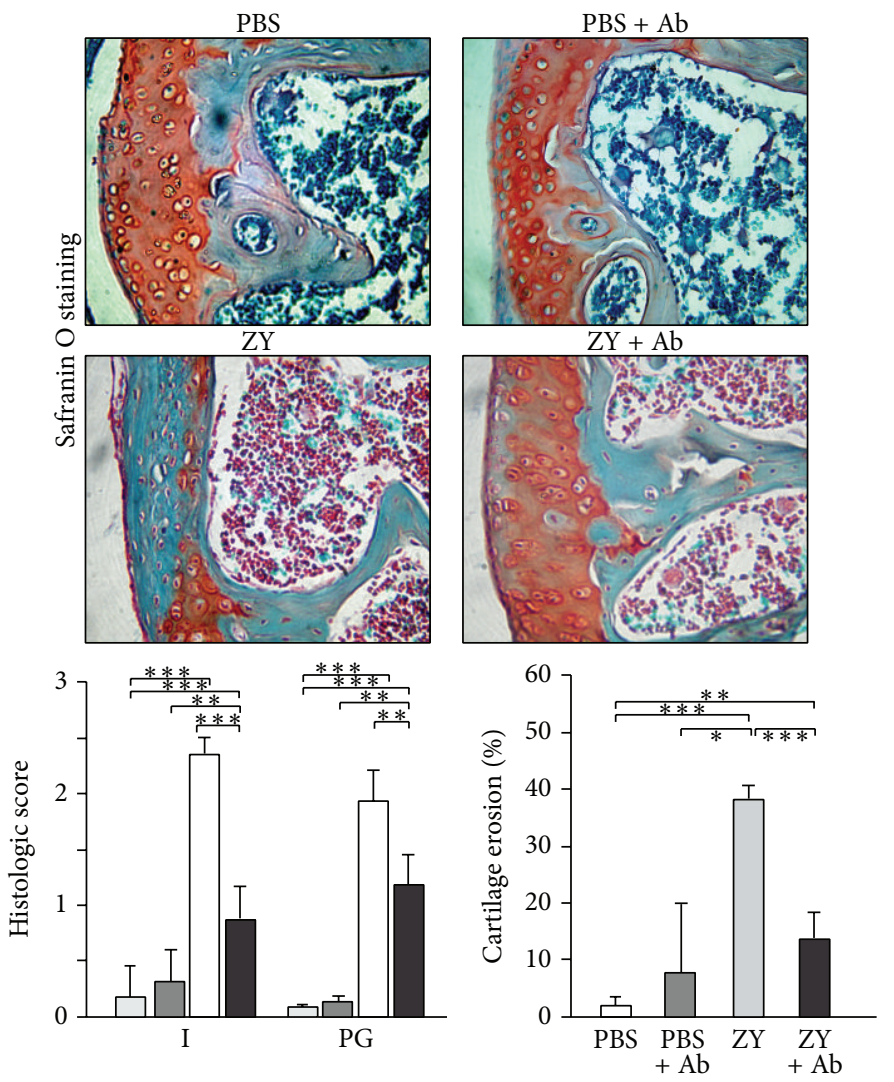

$\square$ PBS

$\square \mathrm{ZY}$

$\square \mathrm{PBS}+\mathrm{Ab}$

ㅁ $\mathrm{ZY}+\mathrm{Ab}$

(c)

Figure 2: Continued. 


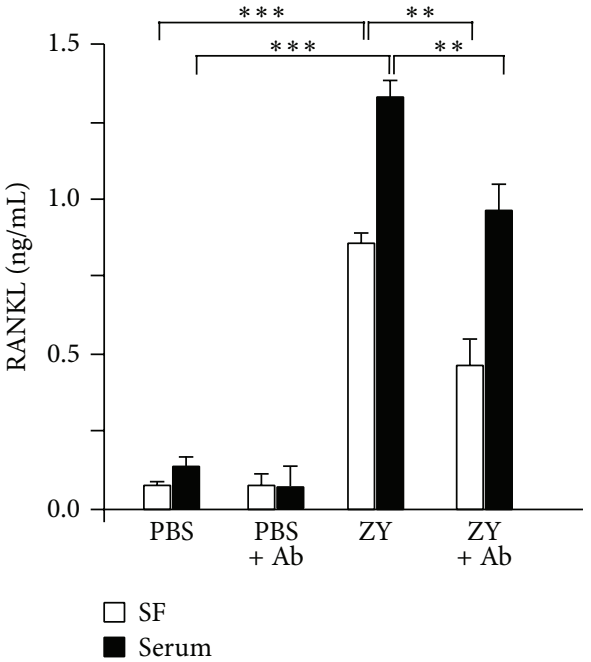

(d)

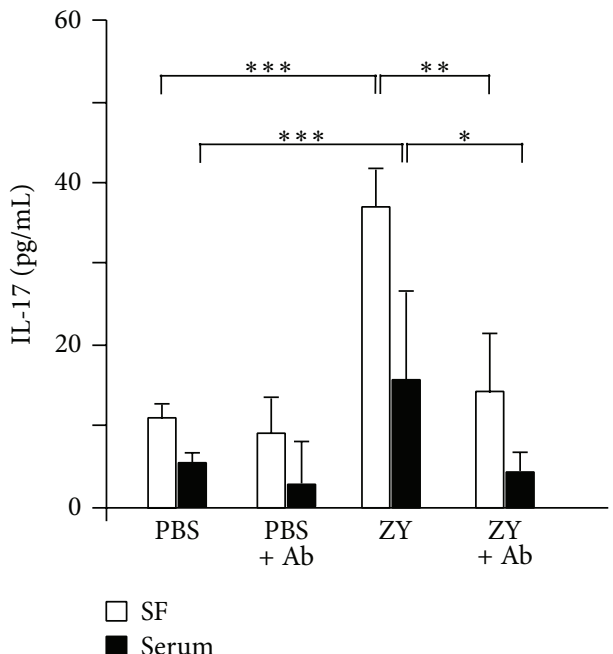

(e)

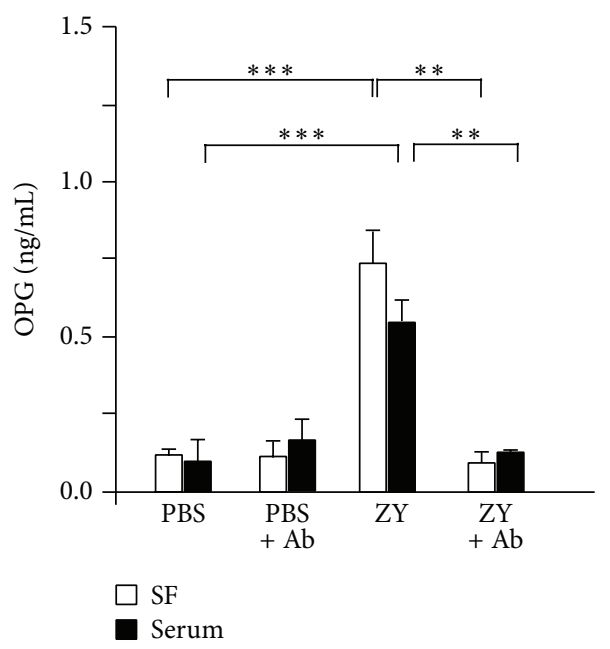

(f)

FIGURE 2: Depletion of $\mathrm{Ly}_{6 \mathrm{G}} \mathrm{CD}^{+} \mathrm{CD}^{+}$cells with monoclonal $1 \mathrm{~A} 8$ antibody (Ab). (a) SCID mice were injected intraperitoneally (i.p) with $1 \mathrm{~A} 8 \mathrm{Ab}(100 \mu \mathrm{g} /$ mouse) at days $-2,+2$, and +4 (arrows showing the injections). The mice received intra-articular (i.a.) knee injection of PBS $\left(10 \mu \mathrm{L}\right.$; naive) or zymosan $\left(200 \mu \mathrm{g} / 10 \mu \mathrm{L}\right.$; arrow ZY) at day 0 . Flow cytometry analysis indicates the loss of Ly6G $\mathrm{G}^{+} \mathrm{CD} 11 \mathrm{~b}^{+}$cells in BM after $\mathrm{Ab}$ treatments. Values are the mean \pm SEM ( $n=7$ mice/group), Student's $t$-test. (b) At day 7 of TLR2 ligand injection (or 3 days after the

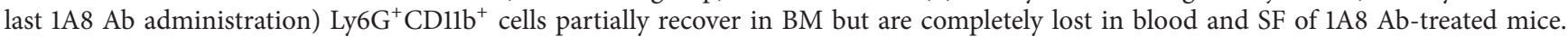
Bars indicate the mean \pm SEM $\left(n=7\right.$ mice/group). ${ }^{*} P<0.05 ;{ }^{* *} P<0.01 ;{ }^{* * *} P<0.001$, Student's $t$-test. (c) The administration of $1 \mathrm{~A} 8 \mathrm{Ab}$ attenuates joint damages as shown on the representative photomicrographs (magnification 100x) and by histological scores for cell infiltration (I), proteoglycan (PG) loss, and percentages of cartilage erosion. Values are the mean \pm SEM ( $n=7$ mice/group). ${ }^{* *} P<0.01$; ${ }^{* * *} P<0.001$, Kruskal-Wallis test and Mann-Whitney $U$-test. Ly6G cell depletion decreases the amounts of RANKL (d), IL-17 (e), and OPG (f) in serum and SF of ZY mice. Values in (d), (e), and (f) are the mean \pm SEM $\left(n=7\right.$ animals/group). ${ }^{*} P<0.05 ;{ }^{* *} P<0.01 ;{ }^{* * *} P<0.001$, Student's $t$-test.

Blood $\mathrm{Ly}_{6 \mathrm{G}} \mathrm{CD}^{+} 1 \mathrm{~b}^{+}$cells from arthritic group expressed RANKL unlike neutrophils from nonarthritic mice. Exogenous IL-17 increased the intensity of RANKL staining but not the frequencies of $\mathrm{RANKL}^{+}$neutrophils (Figures $5(\mathrm{a})$ and 5(b)). Zymosan failed to change RANKL expression but yet in combination with IL-17 enhanced substantially RANKL staining intensity and the frequencies of RANKL ${ }^{+}$ cells (Figures 5(a) and 5(b)).

In the same experimental setting we evaluated the amount of secreted OPG in culture supernatants
(Figure 5(c)). Blood neutrophils from nonarthritic mice produced OPG upon IL-17 and TLR2 ligand stimulation alone or in combination (Figure 5(c)). $\mathrm{Ly}_{6 \mathrm{G}}{ }^{+} \mathrm{CD}_{11 b^{+}}$cells from arthritic mice secreted more OPG in cell cultures than the control cells (Figure 5(c)). By contrast to controls exogenous IL-17 failed to elevate OPG production by neutrophils from arthritic group. The engagement of TLR2 ligand diminished OPG secretion in cultures of $\mathrm{Ly}_{6 \mathrm{G}}{ }^{+} \mathrm{CD} 1 \mathrm{~b}^{+}$cells from arthritic mice. This effect was amplified by IL-17 (Figure 5(c)), simultaneously to the 


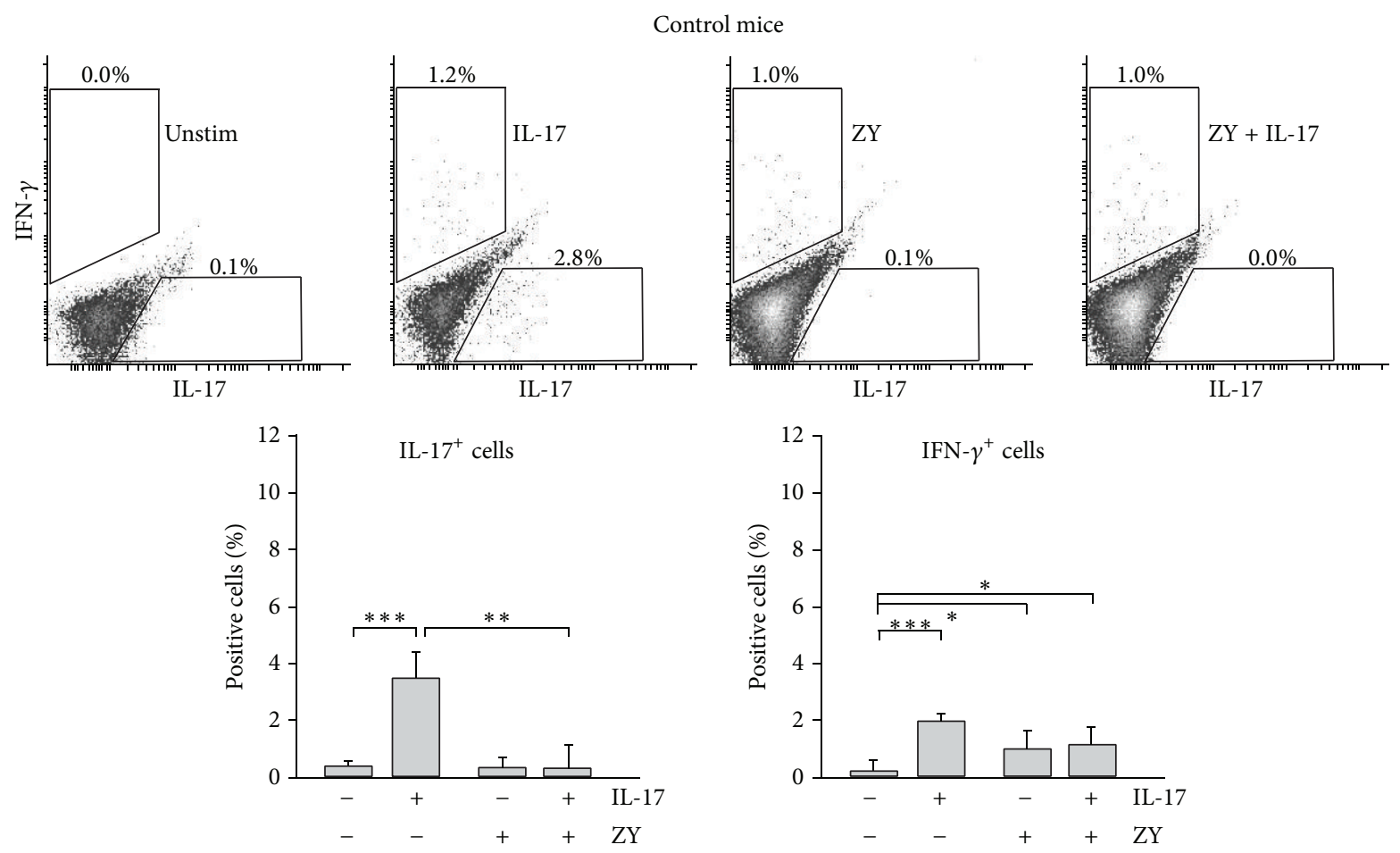

(a)

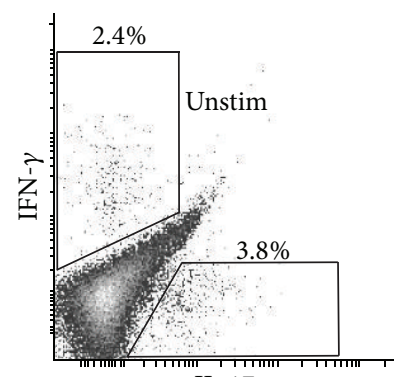

IL-17

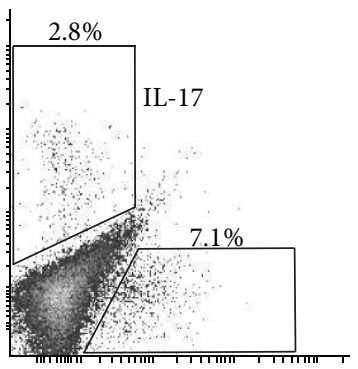

IL-17

IL- $17^{+}$cells

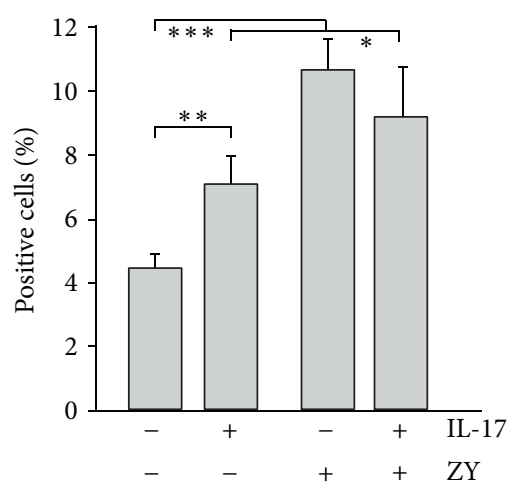

Arthritic mice

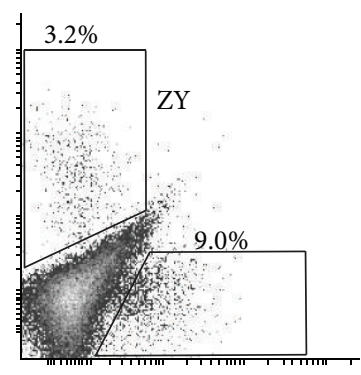

IL-17

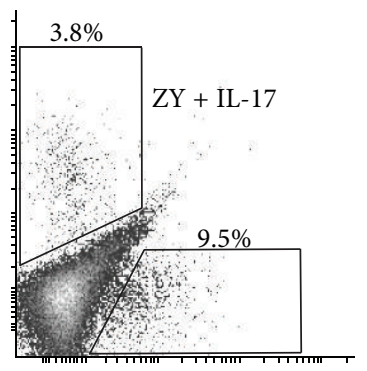

IL-17

IFN- $\gamma^{+}$cells

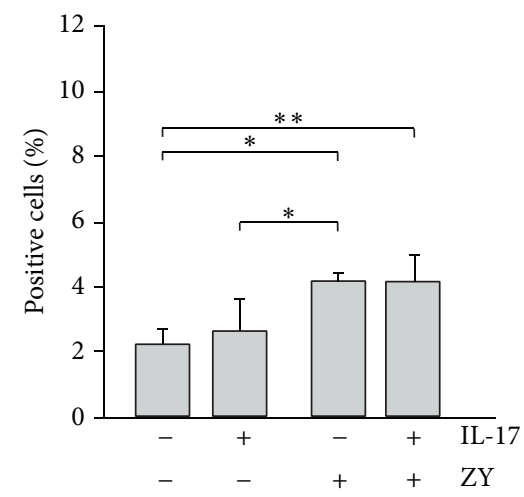

(b)

FIGURE 3: $\mathrm{Ly}_{6 \mathrm{G}}{ }^{+} \mathrm{CD}_{11 \mathrm{~b}}{ }^{+}$cells from arthritic mice produced IL-17 and IFN- $\gamma$. Purified blood neutrophils were cultured $\left(1 \times 10^{6} / \mathrm{mL}\right)$ in medium with GM-CSF $(50 \mathrm{ng} / \mathrm{mL})$ and stimulated with zymosan $(20 \mu \mathrm{g} / \mathrm{mL})$ or/and IL-17 $(40 \mathrm{ng} / \mathrm{mL})$ for 24 hours. Intracellular IL-17 and IFN- $\gamma$ production was evaluated by flow cytometry. (a) Ly $6 \mathrm{G}^{+} \mathrm{CD} 11 \mathrm{~b}^{+}$cells were IFN- $\gamma^{-} / \mathrm{IL}-17^{-}$as shown on dot-plot histograms and graphs. IL-17 induces autocrine IL-17 protein expression and IFN- $\gamma$ synthesis in control cells. (b) Dot-plot histograms and graphs show spontaneous IL-17 and IFN- $\gamma$ production by $\mathrm{Ly}_{6 \mathrm{G}} \mathrm{CD}^{\mathrm{C}} \mathrm{b}^{+}$cells from arthritic group. Zymosan provides stronger signals for IL-17 synthesis than exogenous IL-17 and amplifies the generation of IL- $17^{+}$cells. Bars on graphs (a) and (b) represent the mean \pm SEM ( $n=5$ animals/group; 3 experiments). ${ }^{*} P<0.05 ;{ }^{* *} P<0.01 ;{ }^{* * *} P<0.001$, Student's $t$-test. 


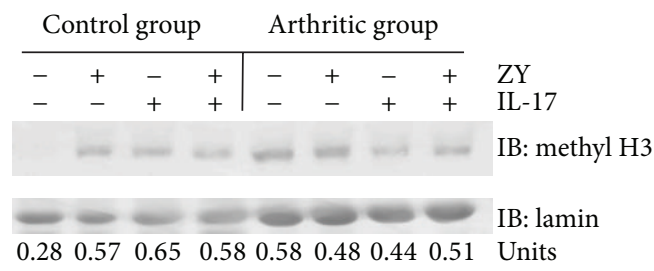

FIGURE 4: Methylated H3K9 (methyl H3) in nuclear extracts from neutrophils. $\mathrm{Ly}_{6 \mathrm{G}} \mathrm{CDD}^{+} \mathrm{b}^{+}$cells were purified and stimulated with $(20 \mu \mathrm{g} / \mathrm{mL})$ or/and IL-17 $(40 \mathrm{ng} / \mathrm{mL})$ for $10 \mathrm{~min}$. Nuclear extracts were obtained as described in Section 2. Methylated H3K9 in nuclear extracts from neutrophils was detected by immunoblot (IB). Lamin in nuclear extracts was used as a control for protein content. Densitometry analyses of IBs were performed by ImageJ 1.42 software (NIH, Bethesda, MD, USA). The density of methyl H3K9 lines was normalized to lamin expression in each sample and was presented in units.

upregulated RANKL expression on $\mathrm{Ly}_{6} \mathrm{G}^{+} \mathrm{CD} 11 \mathrm{~b}^{+}$cells (Figures 5(a) and 5(b)).

3.4. RANKL Expression, $I L-17$, and IFN- $\gamma$ Production of $L y 6 G^{+}$ Cells in SF. In vivo RANKL ${ }^{+}$neutrophils in blood and SF of arthritic mice can originate from mature neutrophils in $\mathrm{BM}$. We found more RANKL ${ }^{+}$cells in $\mathrm{BM} \mathrm{Ly} \mathrm{G}^{+} \mathrm{CD} 1 \mathrm{~b}^{+}$ population from arthritic mice in comparison with control (Figure 6(a)). RANKL-bearing Ly6G $\mathrm{G}^{+}$cells accumulated in $\mathrm{SF}$ of mice with arthritis (Figure 6(b)).

The cytokine production of synovial Ly $6 \mathrm{G}^{+}$cells was also studied. The cell number yield from each mouse was low to run intracellular flow cytometry. Thus, we pooled the SF cells from five mice per group and stained them for Ly6G, IFN- $\gamma$, and IL-17. Flow cytometry analyses were performed on gated Ly $6 \mathrm{G}^{+}$population. Synovial $\mathrm{Ly}_{6 \mathrm{G}}^{+}$cells from arthritic mice expressed IFN- $\gamma$ and IL-17 unlike the cells from control mice (Figure 6(c)). It appeared that most of the cells were IFN$\gamma^{+} \mathrm{IL}_{-17^{+}}$(Figure 6(c)).

\section{Discussion}

The role of neutrophils in joint diseases has been mainly associated with the secretion of proteolytic enzymes and reactive oxygen radicals. Our study showed that the bone destructive potential of neutrophils in arthritis was sustained by increased IL-17 production and RANKL expression and inhibited OPG secretion. In vitro exogenous IL-17 enhanced the functional activity (IL-17 and IFN- $\gamma$ production and RANKL expression) of blood neutrophils from both control and arthritic mice. The effects of IL-17 were amplified by TLR2 ligation on $\mathrm{Ly}_{6} \mathrm{G}^{+} \mathrm{CD}_{11 b}{ }^{+}$cells from arthritic mice only. Therefore, we conclude that targeting TLR2 signaling on neutrophils may limit bone resorption and joint damage in arthritis.

Neutrophils arise from granulocyte precursors in BM. Mature $\mathrm{BM} \mathrm{Ly}_{6} \mathrm{G}^{+} \mathrm{CD}_{11 b^{+}}$cells maintain the replenishment pools in blood and spleen [25]. Various proinflammatory factors and mediators trigger granulopoiesis and enhance the mobilization of mature Ly6G cells from BM [2]. Among them is TLR2 which regulates neutrophil release via transcriptional upregulation of G-protein-coupled receptor kinase-2 and chemokine receptor CXCR2 downregulation [26]. In our model the stimulatory effects of TLR2 on granulopoiesis and neutrophils trafficking was confirmed by increased frequencies of Ly $6 \mathrm{G}^{+} \mathrm{CD}_{11 \mathrm{~b}^{+}}$cells in BM, blood, and SF and by CD69 expression on circulating neutrophils. In vitro neutrophils upregulate $\mathrm{CD} 69$ in response to various stimuli that induce cell activation or priming like TLRs, TNF- $\alpha$, GM-CSF, IFN$\gamma$, or IFN- $\alpha$ [27].

The depletion of neutrophils by specific antibody shows a crucial role of neutrophils for disease progression in a model of collagen-antibody induced arthritis [28]. Two clones of Abs are available for neutrophil elimination, clones RB6$8 \mathrm{C} 5$, and $1 \mathrm{~A} 8$. While $1 \mathrm{~A} 8 \mathrm{Ab}$ recognizes Ly6G, RB6-8C5 binds to two Ly6 isoforms, Ly6G, and Ly6C. Besides on neutrophils, Ly6C is found on dendritic cells, subpopulations of lymphocytes, and monocytes [28]. We used more a specific 1A8 clone to target the population of mature neutrophils. $\mathrm{Ly}_{6 \mathrm{G}} \mathrm{C}^{+} \mathrm{CD} 11 \mathrm{~b}^{+}$cells disappeared from blood and SFs of $1 \mathrm{~A} 8$ $\mathrm{Ab}$-treated mice. The administration of $1 \mathrm{~A} 8 \mathrm{Ab}$ reduced the degree of joint damages as shown by decreased scores for cell infiltration, cartilage erosion, and PG loss and diminished amount of bone-erosion accelerating marker RANKL in SF and serum. $1 \mathrm{~A} 8 \mathrm{Ab}$ completely abrogated OPG and IL17 production indicating that $\mathrm{Ly}_{6} \mathrm{G}^{+} \mathrm{CD} 11 \mathrm{~b}^{+}$cells were the source of both factors in serum and SF. We think that neutrophils may provide a certain level of IL-17 that later on during the development of arthritis can be amplified by mast cells, monocytes, or T cells secreting also IL-17 [29, 30]. In RA patients as well as in our study IL-17 appears at initial stage of disease and before the disease onset [9-11]. Moreover, the level of IL-17 in SF can predict the progression of joint damage in RA patients [12].

Three recent studies have shown that neutrophils produced IL-17 under infectious and allergic conditions [31-33]. Intracellular IL-17 production was detected in synovial and blood Ly $6 \mathrm{G}^{+} \mathrm{CD}_{11 b^{+}}$cells from arthritic BALB/c mice. IL-17 protein synthesis is regulated by IL-17 gene as well as of genes for key transcription factors. Transcription is fine-tuned by epigenetic histone modifications such as methylation and acetylation. We observed the expression of monomethylated H3K9 in neutrophils from arthritic mice but not in control cells. The methylation of H3K9 induces gene silencing and is associated with human and mouse granulocytes differentiation and abnormalities in myeloid leukemia [34, 35]. In our study IL-17 triggered its own production and H3K9 methylation in nonarthritic neutrophils proposing that certain genes are silenced in order to acquire IL-17 expression. Epigenetic modification of IL-17 gene expression is mainly studied in T cells. Considerable amounts of IL-17 can be maintained in $\mathrm{T}$ cells by increasing histone $\mathrm{H} 3$ acetylation and methylation at the IL-17 gene promoter [36]. Our data are too preliminary, but they outline the interest to study IL-17 transcription and epigenetic modification of IL-17dependent gene expression in neutrophils and granulocytes and in neutrophils in particular. 

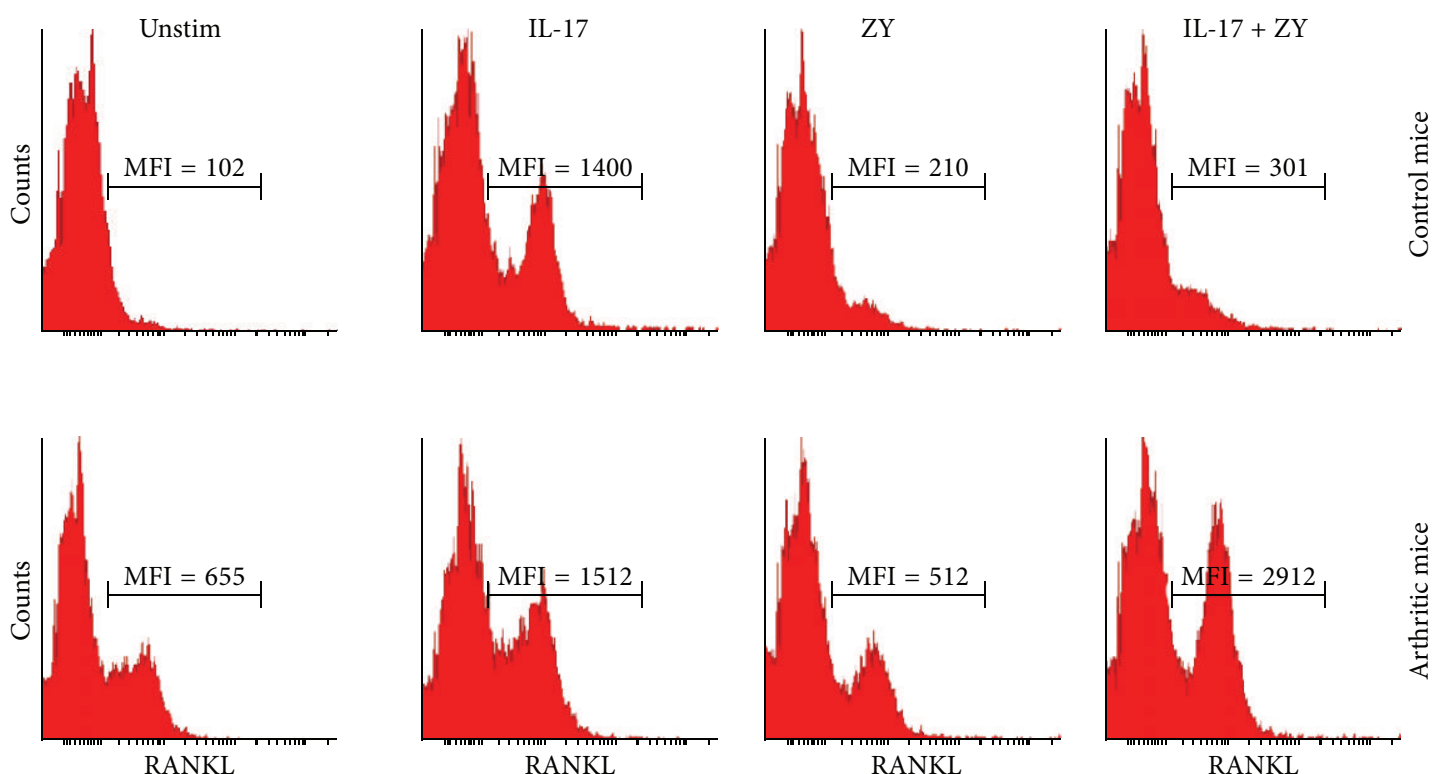

(a)

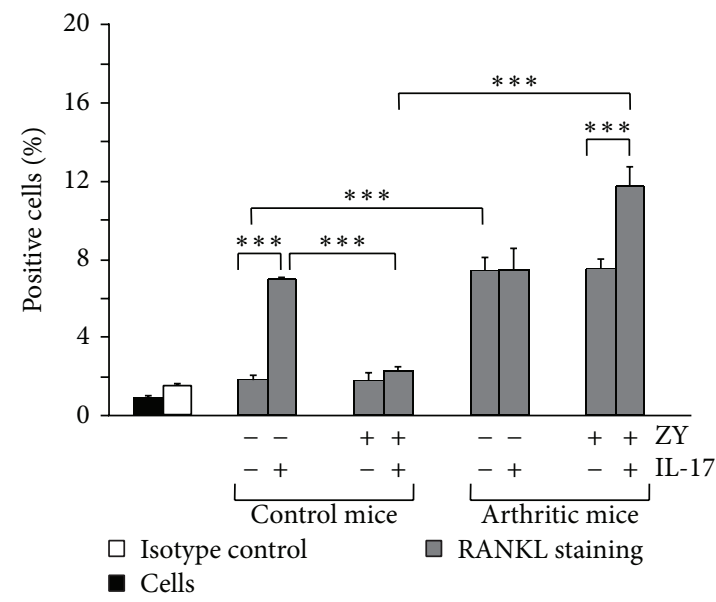

(b)

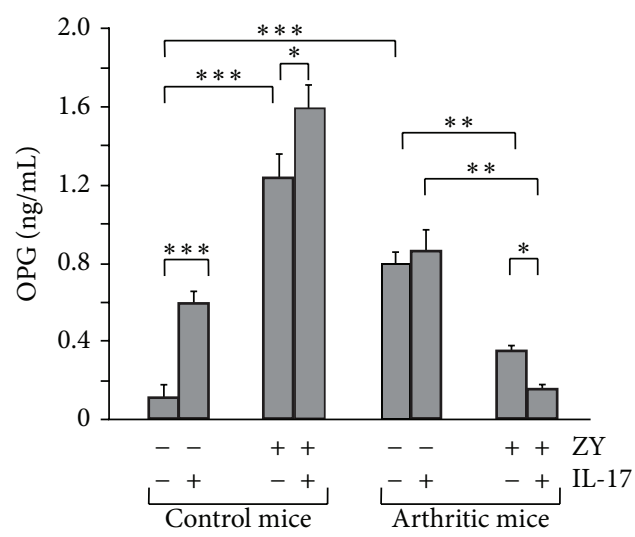

(c)

FIGURE 5: RANKL expression and OPG secretion by neutrophils were regulated by TLR2 ligand and IL-17. Purified neutrophils were stimulated as in Figure 3. (a) Representative histograms show RANKL expression on blood neutrophils from nonarthritic and arthritic mice. MFI: mean fluorescence intensity. (b) Graphs indicate that IL-17 increases the frequencies of RANKL ${ }^{+}$neutrophils in the control group. More RANKL ${ }^{+}$ cells are found after stimulation with TLR2 and IL-17 in arthritic group. (c) IL-17 and zymosan induce OPG secretion by control neutrophils and inhibit OPG production by cells from arthritic mice. Values in (b) and (c) are the mean \pm SEM ( $n=5$ animals/group; 3 experiments). ${ }^{*} P<0.05 ;{ }^{* *} P<0.01 ;{ }^{* * *} P<0.001$, Student's $t$-test.

Ly $6 \mathrm{G}^{+} \mathrm{CD} 11 b^{+}$cells from nonarthritic and arthritic mice were sensitive to IL-17 stimulation, but they responded differently to simultaneous IL-17R and TLR2 ligation in vitro. While zymosan blocked the effects of exogenous IL17 on neutrophils from nonarthritic mice, it amplified IL-17 production in $\mathrm{Ly}_{6 \mathrm{G}}{ }^{+} \mathrm{CD} 11 \mathrm{~b}^{+}$cells from arthritic group. TLR2 and IL-17 signaling pathways can interfere at various levels. In particular, a conserved motif in the cytoplasmic domain of receptor for IL-17 with homology to the TIR domain has been identified [37]. TIR domain has a specific docking site for adaptor protein MyD88 that allows the involvement of TLR2 signaling pathway. Common transduction proteins can sustain the assembly of IL-17R and can regulate the strength of receptor expression [38]. At transcriptional level both pathways can interfere through NF- $\kappa \mathrm{B}$ activation and pathway (reviewed by [39]). We speculated that TLR2 and IL-17R pathways directly compete for intracellular kinases, adaptor proteins, or transcription factors. In neutrophils from nonarthritic mice activated molecules or factors were limited and less available for both signaling. By contrast Ly $6 \mathrm{G}^{+} \mathrm{CD} 11 b^{+}$cells from arthritic group were primed or activated (as shown by the expression of CD69) and in turn they have in disposal high numbers of common transduction molecules and transcription factors. Thus both pathways via their crosstalk can provide a mechanism for regulation of neutrophils activities in health and disease. 

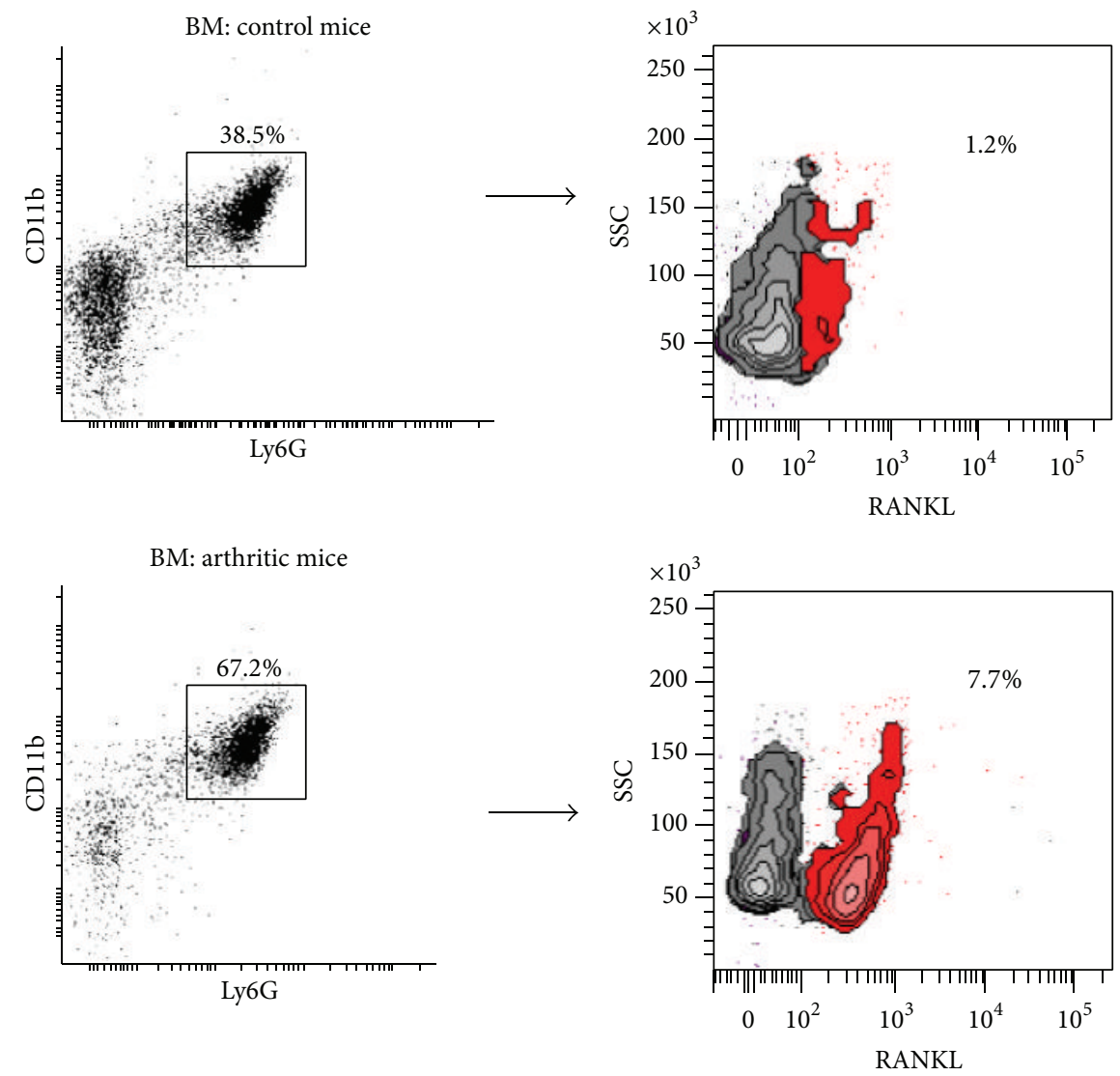

(a)

SF

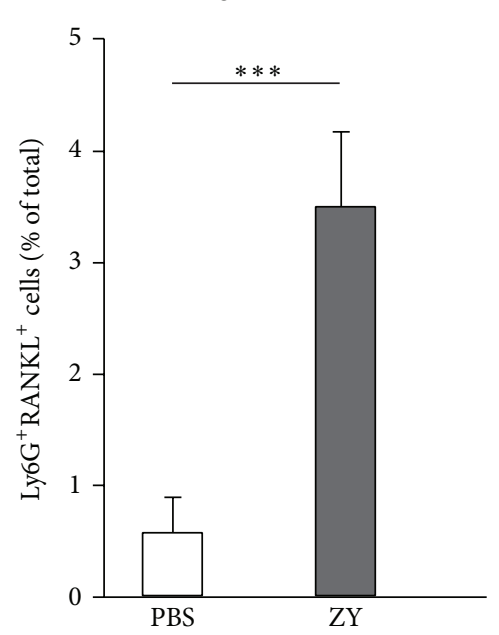

(b)
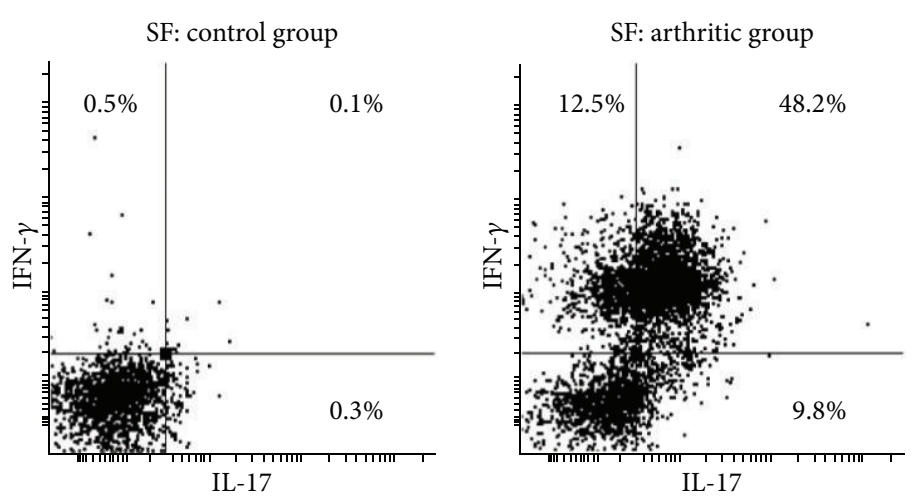

(c)

FIGURE 6: RANKL expression, IL-17, and IFN- $\gamma$ production of $\mathrm{Ly}_{6 \mathrm{G}}^{+}$cells in BM or SF. (a) Dot-plot histograms show increased frequencies of $\mathrm{Ly}_{6 \mathrm{G}} \mathrm{CD}^{+} 1 \mathrm{~b}^{+}$cells in $\mathrm{BM}$ of mice with arthritis than in control group. The density plots indicate a higher distribution of RANKL ${ }^{+}$cells in Ly $6 \mathrm{G}^{+} \mathrm{CD}_{11 b^{+}}$population from arthritic group (SSC: side scatter). (b) RANKL-bearing Ly $6 \mathrm{G}^{+}$cells accumulated in SF of mice with arthritis. Bars represent the mean \pm SEM $\left(n=5\right.$ animals/group; 3 experiments). ${ }^{* * *} P<0.001$, Student's $t$-test. (c) Synovial cells from 5 animals per group were pooled and intracellular cytokine production was performed on gated Ly $6 \mathrm{G}^{+}$cells. Representative dot-plot histograms show IFN- $\gamma$ and IL-17 production in Ly6G ${ }^{+}$cells from SF of mice with arthritis (day 7) ( $n=5$ animals/group; representative from 3 experiments). 
IL-17 increases the recruitment of neutrophils at the site of inflammation and influences the production of various proinflammatory mediators [11]. We observed that IL-17 initiated IFN- $\gamma$ production in $\mathrm{Ly}_{6} \mathrm{G}^{+} \mathrm{CD}_{11 b^{+}}$cells from nonarthritic mice but failed to increase the frequencies of IFN- $\gamma^{+}$cells in arthritic group. IL-17 can reduce degradation of mRNA for certain cytokines and can enhance cell responsiveness to second stimuli [40]. Indeed IL-17-producing neutrophils act proximally and are required for IFN- $\gamma$ production [33]. In vivo TLRs, various proinflammatory cytokines, cell environment, and disease stage can elicit the action of IL-17 on neutrophils. In arthritic synovium IL-17 activates fibroblasts and synoviocytes to produce IL- 6 , IL- 8 , TNF- $\alpha$, and GMCSF and to express TLR2 favoring cytokine production, activation, and survival of neutrophils [41, 42]. In such environment most of $\mathrm{Ly}_{6} \mathrm{G}^{+}$cells in SF were double positive for IFN- $\gamma$ and IL-17. The specific factors and cell populations in blood created the conditions that likely generated single IFN $-\gamma^{+}$or IL- $17^{+}$neutrophils. In cell cultures from arthritic group TLR2 restimulation sustained this phenotype and enhanced the generation of single IFN- $\gamma^{+}$and IL- $17^{+}$cells.

Bone destructive processes such as bone erosion and bone resorption depend on the activation of osteoclasts. These cells are sensitive to the action of IFN- $\gamma$ and IL-17, but the RANKL/OPG system is crucial for their differentiation and maturation. Various studies show a correlation between severity of bone diseases and RANKL/OPG ratio in serum and SF (reviewed by [43]). OPG is a soluble protein from the TNF receptor superfamily and it inhibits osteoclast differentiation and activity. We assume that neutrophils at the initial stage of disease secreted OPG because the molecule was absent in serum and SF after cell depletion by $1 \mathrm{~A} 8 \mathrm{Ab}$. Experiments in vitro confirmed that OPG was released by blood neutrophils from nonarthritic mice upon TLR2 stimulation or spontaneously by neutrophils from TLR2 ligandinjected group. $\mathrm{Ly}_{6 \mathrm{G}}{ }^{+} \mathrm{CD} 1 \mathrm{~b}^{+}$cells from arthritic mice failed to produce OPG after zymosan restimulation. This altered responsiveness to repeated stimulation might maintain low OPG levels during the development of arthritis that in turn can sustain osteoclastogenesis and osteoclast activation. We think that such mechanism may dominate at late stages of disease when more neutrophils are accumulated in SF.

OPG decoy receptor, RANKL, exists in two isoforms, a soluble protein, and a membrane bound protein. The latter is sensitive to the cleavage by proteases. Thus, the neutrophils producing proteases may affect the amount of soluble RANKL in biological fluids. Indeed we found that after neutrophil depletion the concentrations of RANKL decreased in serum and SF of zymosan-injected mice.

The membrane bound RANKL is expressed by BM cells, precursors of osteoclasts, and stromal cells [43]. In vivo TLR2 ligand induced RANKL expression on $\mathrm{Ly}_{6} \mathrm{G}^{+} \mathrm{CD}_{11 \mathrm{~b}}{ }^{+}$cells in BM. Despite that RANKL ${ }^{+}$pool of $\mathrm{Ly}_{6 \mathrm{G}^{+}}$cells was small, it probably maintained the frequencies of $\mathrm{RANKL}^{+}$neutrophils in circulation and even contributed to the accumulation of RANKL-bearing cells in SF at early stage of disease (day 7). The study describing RANKL expression on blood neutrophils from RA patients supported our data [19]. The same authors indicated the role of the environmental factors since neutrophils from healthy donors upregulated RANKL after incubation with SF from RA patients [19]. We found that exogenous IL-17 induced RANKL expression on RANKLnegative blood neutrophils (control) and increased the density of surface RANKL on RANKL-bearing $\mathrm{Ly} 6 \mathrm{G}^{+} \mathrm{CD} 11 \mathrm{~b}^{+}$ cells (arthritic group). TLR2 engagement potentiated the IL17-mediated RANKL expression only on neutrophils from arthritic mice and inhibited OPG secretion in cell cultures at the same time. Thus we built the hypothesis that TLR2 signaling sustained the bone destructive potential of neutrophils by an interference with IL-17-dependent RANKL/OPG system.

In summary, our study showed that (i) exogenous IL17 induced autocrine IL-17 production, IFN- $\gamma$ synthesis, and RANKL expression on blood neutrophils from nonarthritic mice and these effects were inhibited upon simultaneous TLR2 stimulation; (ii) $\mathrm{Ly}_{6} \mathrm{G}^{+} \mathrm{CD} 1 \mathrm{~b}^{+}$cells from arthritic group produced IL-17, IFN- $\gamma$, and OPG spontaneously and expressed RANKL; (iii) TLR2 increased IL-17-mediated RANKL expression and inhibited OPG secretion by neutrophils from arthritic mice. Together these data suggest that TLR2 signaling might be a good target to limit the bone destructive potential of neutrophils in joint diseases.

\section{Conflict of Interests}

The authors declare that they have no conflict of interests.

\section{Acknowledgments}

The work was financially supported by Inter-Pasteurien Concerted Actions Grant A05_11, France, and by Grant 94/23551 from the Program BG051PO001/3.3-05-0001 of Bulgarian Ministry of Education and Science and European Social Fund. Viktoriya Milanova, Petya Dimitrova, and Nina Ivanovska were involved in the acquisition of the data. Petya Dimitrova designed the research and study conception. All authors were involved in drafting the paper or revising it critically for important intellectual content, and all authors approved the final version to be published. Viktoriya Milanova is a Ph.D. student at the Department of Immunology, Institute of Microbiology, Sofia, Bulgaria, and this work will be a part of her Ph.D. thesis.

\section{References}

[1] H. L. Wright, B. Chikura, R. C. Bucknall, R. J. Moots, and S. W. Edwards, "Changes in expression of membrane TNF, NF- $\kappa$ B activation and neutrophil apoptosis during active and resolved inflammation," Annals of the Rheumatic Diseases, vol. 70, no. 3, pp. 537-543, 2011.

[2] C. Nathan, "Neutrophils and immunity: challenges and opportunities," Nature Reviews Immunology, vol. 6, no. 3, pp. 173-182, 2006.

[3] I. Sabroe, S. K. Dower, and M. K. B. Whyte, "The role of Toll-like receptors in the regulation of neutrophil migration, activation, and apoptosis," Clinical Infectious Diseases, vol. 41, supplement 7, pp. S421-S426, 2005.

[4] A. Ozinsky, D. M. Underhill, J. D. Fontenot et al., “The repertoire for pattern recognition of pathogens by the innate immune 
system is defined by cooperation between Toll-like receptors," Proceedings of the National Academy of Sciences of the United States of America, vol. 97, no. 25, pp. 13766-13771, 2000.

[5] K. Takeda and S. Akira, "TLR signaling pathways," Seminars in Immunology, vol. 16, no. 1, pp. 3-9, 2004.

[6] E. M. Pålsson-McDermott and L. A. J. O’Neill, “The potential of targeting Toll-like receptor 2 in autoimmune and inflammatory diseases," Irish Journal of Medical Science, vol. 176, no. 4, pp. 253 260, 2007.

[7] H. L. Rosenzweig, M. J. Jann, E. E. Vance, S. R. Planck, J. T. Rosenbaum, and M. P. Davey, "Nucleotide-binding oligomerization domain 2 and Toll-like receptor 2 function independently in a murine model of arthritis triggered by intraarticular peptidoglycan," Arthritis \& Rheumatism, vol. 62, no. 4, pp. 10511059, 2010.

[8] M. E. Frasnelli, D. Tarussio, V. Chobaz-Péclat, N. Busso, and A. So, "TLR2 modulates inflammation in zymosan-induced arthritis in mice," Arthritis Research \& Therapy, vol. 7, no. 2, pp. R370-379, 2005.

[9] K. Raza, F. Falciani, S. J. Curnow et al., "Early rheumatoid arthritis is characterized by a distinct and transient synovial fluid cytokine profile of T cell and stromal cell origin," Arthritis Research \& Therapy, vol. 7, no. 4, pp. R784-795, 2005.

[10] S. Kotake, N. Udagawa, N. Takahashi et al., "IL-17 in synovial fluids from patients with rheumatoid arthritis is a potent stimulator of osteoclastogenesis," Journal of Clinical Investigation, vol. 103, no. 9, pp. 1345-1352, 1999.

[11] H. Yamada, "Current perspectives on the role of IL-17 in autoimmune disease," Journal of Inflammation Research, vol. 3, no. 1, pp. 33-44, 2010.

[12] B. W. Kirkham, M. N. Lassere, J. P. Edmonds et al., "Synovial membrane cytokine expression is predictive of joint damage progression in rheumatoid arthritis: a two-year prospective study (the DAMAGE study cohort)," Arthritis \& Rheumatism, vol. 54, no. 4, pp. 1122-1131, 2006.

[13] H. Kokkonen, I. Söderström, J. Rocklöv, G. Hallmans, K. Lejon, and S. R. Dahlqvist, "Up-regulation of cytokines and chemokines predates the onset of rheumatoid arthritis," Arthritis \& Rheumatism, vol. 62, no. 2, pp. 383-391, 2010.

[14] E. Lubberts, L. A. B. Joosten, F. A. J. Van de Loo, P. Schwarzenberger, J. Kolls, and W. B. Van den Berg, "Overexpression of IL-17 in the knee joint of collagen type II immunized mice promotes collagen arthritis and aggravates joint destruction," Inflammation Research, vol. 51, no. 2, pp. 102-104, 2002.

[15] E. Lubberts, M. I. Koenders, B. Oppers-Walgreen et al., "Treatment with a neutralizing anti-murine interleukin-17 antibody after the onset of collagen-induced arthritis reduces joint inflammation, cartilage destruction, and bone erosion," Arthritis \& Rheumatism, vol. 50, no. 2, pp. 650-659, 2004.

[16] E. M. Moran, R. Mullan, J. McCormick et al., "Human rheumatoid arthritis tissue production of IL-17A drives matrix and cartilage degradation: synergy with tumour necrosis factor$\alpha$, Oncostatin $\mathrm{M}$ and response to biologic therapies," Arthritis Research \& Therapy, vol. 11, no. 4, article R113, 2009.

[17] H. Ito, H. Yamada, T. N. Shibata, H. Mitomi, S. Nomoto, and S. Ozaki, "Dual role of interleukin-17 in pannus growth and osteoclastogenesis in rheumatoid arthritis," Arthritis Research \& Therapy, vol. 13, no. 1, article R14, 2011.

[18] J. J. Yu, M. J. Ruddy, G. C. Wong et al., "An essential role for IL-17 in preventing pathogen-initiated bone destruction: recruitment of neutrophils to inflamed bone requires IL-17 receptor-dependent signals," Blood, vol. 109, no. 9, pp. 37943802, 2007.

[19] P. E. Poubelle, A. Chakravarti, M. J. Fernandes, K. Doiron, and A.-A. Marceau, "Differential expression of RANK, RANK$\mathrm{L}$, and osteoprotegerin by synovial fluid neutrophils from patients with rheumatoid arthritis and by healthy human blood neutrophils," Arthritis Research \& Therapy, vol. 9, article R25, 2007.

[20] P. Dimitrova, N. Ivanovska, L. Belenska et al., "Abrogated RANKL expression in properdin-deficient mice is associated with better outcome from collagen-antibody-induced arthritis," Arthritis Research \& Therapy, vol. 14, no. 4, p. R173, 2012.

[21] N. Ivanovska and P. Dimitrova, "Bone resorption and remodeling in murine collagenase-induced osteoarthritis after administration of glucosamine," Arthritis Research \& Therapy, vol. 13, no. 2, article R44, 2011.

[22] P. Dimitrova, A. Toncheva, V. Gyurkovska, and N. Ivanovska, "Involvement of soluble receptor activator of nuclear factor- $\kappa \mathrm{B}$ ligand (sRANKL) in collagenase-induced murine osteoarthritis and human osteoarthritis," Rheumatology International, vol. 32, no. 5, pp. 1317-1325, 2012.

[23] A. Toncheva, M. Remichkova, K. Ikonomova, P. Dimitrova, and N. Ivanovska, "Inflammatory response in patients with active and inactive osteoarthritis," Rheumatology International, vol. 29, no. 10, pp. 1197-1203, 2009.

[24] P. Dimitrova, N. Ivanovska, W. Schwaeble, V. Gyurkovska, and C. Stover, "The role of properdin in murine zymosan-induced arthritis," Molecular Immunology, vol. 47, no. 7-8, pp. 1458-1466, 2010.

[25] R. Boxio, C. Bossenmeyer-Pourié, N. Steinckwich, C. Dournon, and O. Nüße, "Mouse bone marrow contains large numbers of functionally competent neutrophils," Journal of Leukocyte Biology, vol. 75, no. 4, pp. 604-611, 2004.

[26] J. C. Alves-Filho, A. Freitas, F. O. Souto et al., "Regulation of chemokine receptor by Toll-like receptor 2 is critical to neutrophil migration and resistance to polymicrobial sepsis," Proceedings of the National Academy of Sciences of the United States of America, vol. 106, no. 10, pp. 4018-4023, 2009.

[27] F. Atzeni, M. Schena, A. M. Ongari et al., "Induction of CD69 activation molecule on human neutrophils by GM-CSF, IFN$\gamma$, and IFN- $\alpha$," Cellular Immunology, vol. 220, no. 1, pp. 20-29, 2002.

[28] J. M. Daley, A. A. Thomay, M. D. Connolly, J. S. Reichner, and J. E. Albina, "Use of Ly6G-specific monoclonal antibody to deplete neutrophils in mice," Journal of Leukocyte Biology, vol. 83, no. 1, pp. 64-70, 2008.

[29] J. G. Barin, G. C. Baldeviano, M. V. Talor et al., "Macrophages participate in IL-17-mediated inflammation," European Journal of Immunology, vol. 42, no. 3, pp. 726-736, 2012.

[30] T. J. Kenna and M. A. Brown, "The role of IL-17-secreting mast cells in inflammatory joint disease," Nature Review of Rheumatology, vol. 9, no. 6, pp. 375-379, 2013.

[31] S. Ferretti, O. Bonneau, G. R. Dubois, C. E. Jones, and A. Trifilieff, "Il-17, produced by lymphocytes and neutrophils, is necessary for lipopolysaccharide-induced airway neutrophilia: IL-15 as a possible trigger," Journal of Immunology, vol. 170, no. 4, pp. 2106-2112, 2003.

[32] C. Ramirez-Velazquez, E. C. Castillo, L. Guido-Bayardo, and V. Ortiz-Navarrete, "IL-17-producing peripheral blood CD177 neutrophils increase in allergic asthmatic subjects," Allergy Asthma \& Clinicalal Immunology, vol. 9, no. 1, p. 23, 2013. 
[33] L. Li, L. Huang, A. L. Vergis et al., "IL-17 produced by neutrophils regulates IFN- $\gamma$-mediated neutrophil migration in mouse kidney ischemia-reperfusion injury," Journal of Clinical Investigation, vol. 120, no. 1, pp. 331-342, 2010.

[34] E. Lukášová, Z. Kořistek, M. Falk et al., "Methylation of histones in myeloid leukemias as a potential marker of granulocyte abnormalities," Journal of Leukocyte Biology, vol. 77, no. 1, pp. 100-111, 2005.

[35] D. E. Olins and A. L. Olins, "Granulocyte heterochromatin: defining the epigenome," BMC Cell Biology, vol. 6, article 39, 2005.

[36] A. M. Akimzhanov, X. O. Yang, and C. Dong, "Chromatin remodeling of interleukin-17 (IL-17)-IL-17F cytokine gene locus during inflammatory helper T cell differentiation," The Journal of Biological Chemistry, vol. 282, no. 9, pp. 5969-5972, 2007.

[37] M. Novatchkova, A. Leibbrandt, J. Werzowa, A. Neubüser, and F. Eisenhaber, "The STIR-domain superfamily in signal transduction, development and immunity," Trends in Biochemical Sciences, vol. 28, no. 5, pp. 226-229, 2003.

[38] J. M. Kramer, W. Hanel, F. Shen et al., "Cutting edge: identification of a pre-ligand assembly domain (PLAD) and ligand binding site in the IL-17 receptor," Journal of Immunology, vol. 179, no. 10, pp. 6379-6383, 2007.

[39] S. L. Gaffen, "An overview of IL-17 function and signaling," Cytokine, vol. 43, no. 3, pp. 402-407, 2008.

[40] T. Hamilton, X. Li, M. Novotny et al., "Cell type- and stimulusspecific mechanisms for post-transcriptional control of neutrophil chemokine gene expression," Journal of Leukocyte Biology, vol. 91, no. 3, pp. 377-383, 2012.

[41] M. Pierer, J. Rethage, R. Seibl et al., "Chemokine secretion of rheumatoid arthritis synovial fibroblasts stimulated by Toll-like receptor 2 ligands," Journal of Immunology, vol. 172, no. 4, pp. 1256-1265, 2004.

[42] G. Parsonage, A. Filer, M. Bik et al., "Prolonged, granulocytemacrophage colony-stimulating factor-dependent, neutrophil survival following rheumatoid synovial fibroblast activation by IL-17 and TNFalpha," Arthritis Research \& Therapy, vol. 10, no. 2, article R47, 2008.

[43] B. F. Boyce and L. Xing, "Functions of RANKL/RANK/OPG in bone modeling and remodeling," Archives of Biochemistry \& Biophysics, vol. 473, no. 2, pp. 139-146, 2008. 


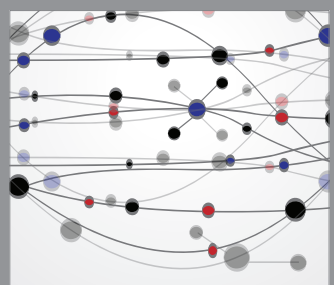

The Scientific World Journal
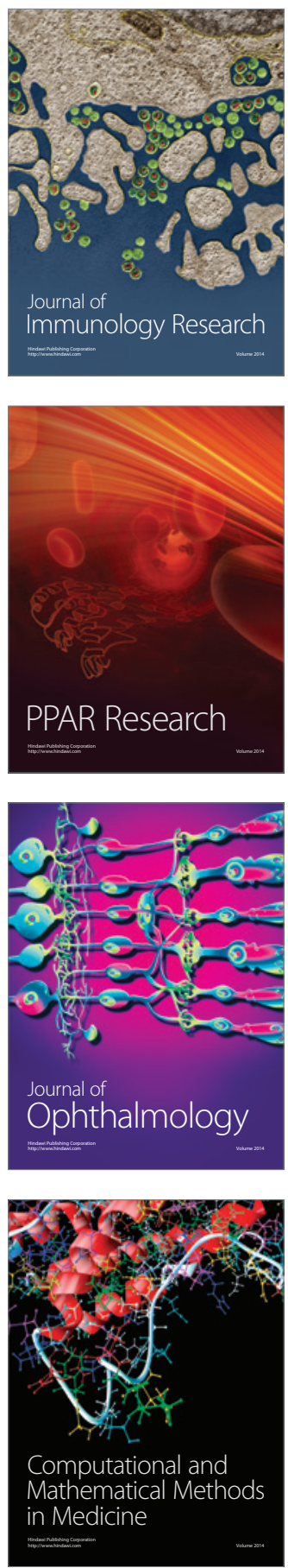

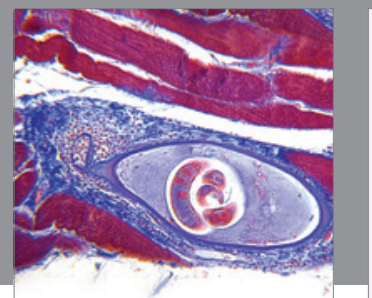

Gastroenterology

Research and Practice
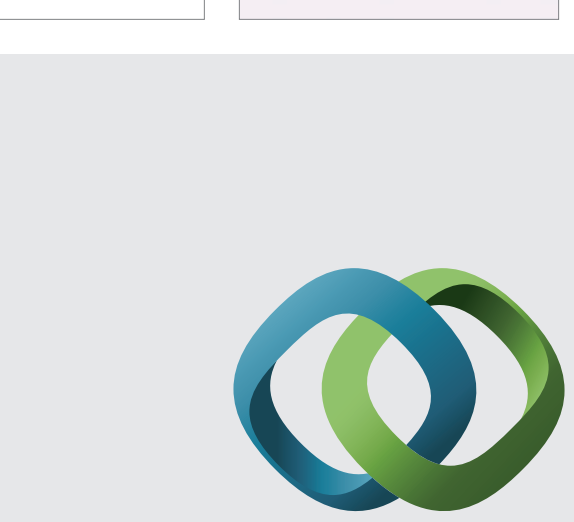

\section{Hindawi}

Submit your manuscripts at

http://www.hindawi.com
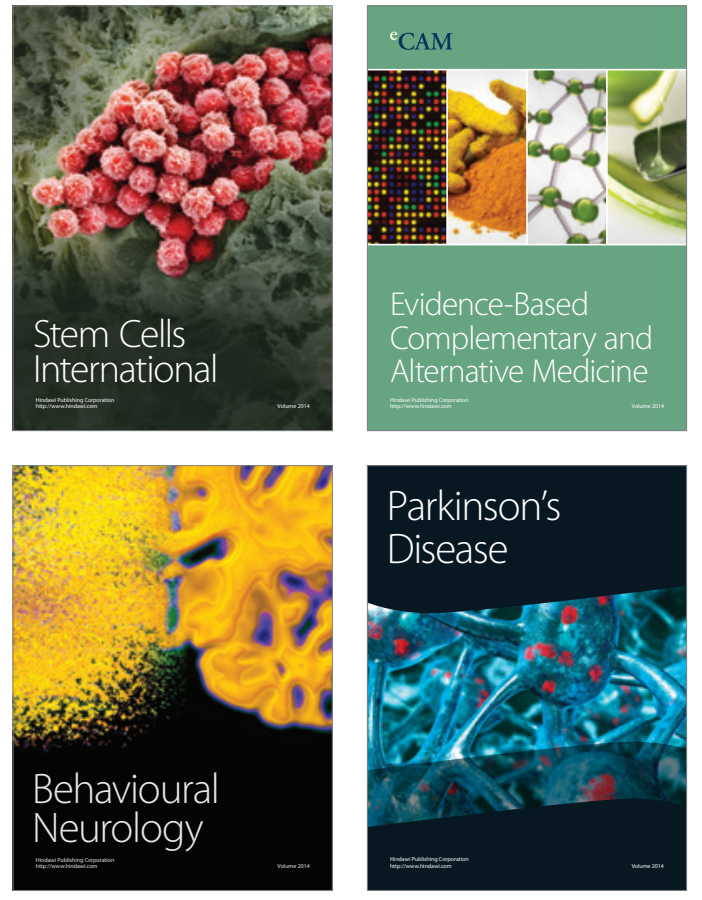
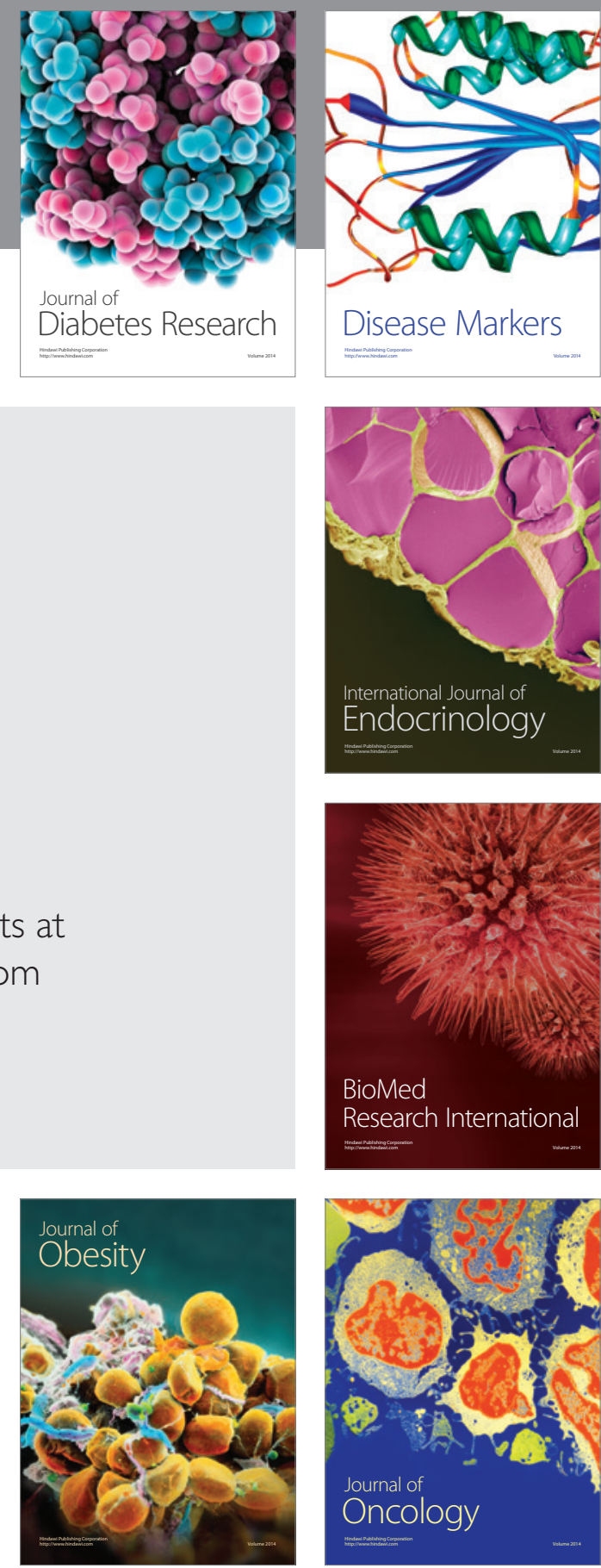

Disease Markers
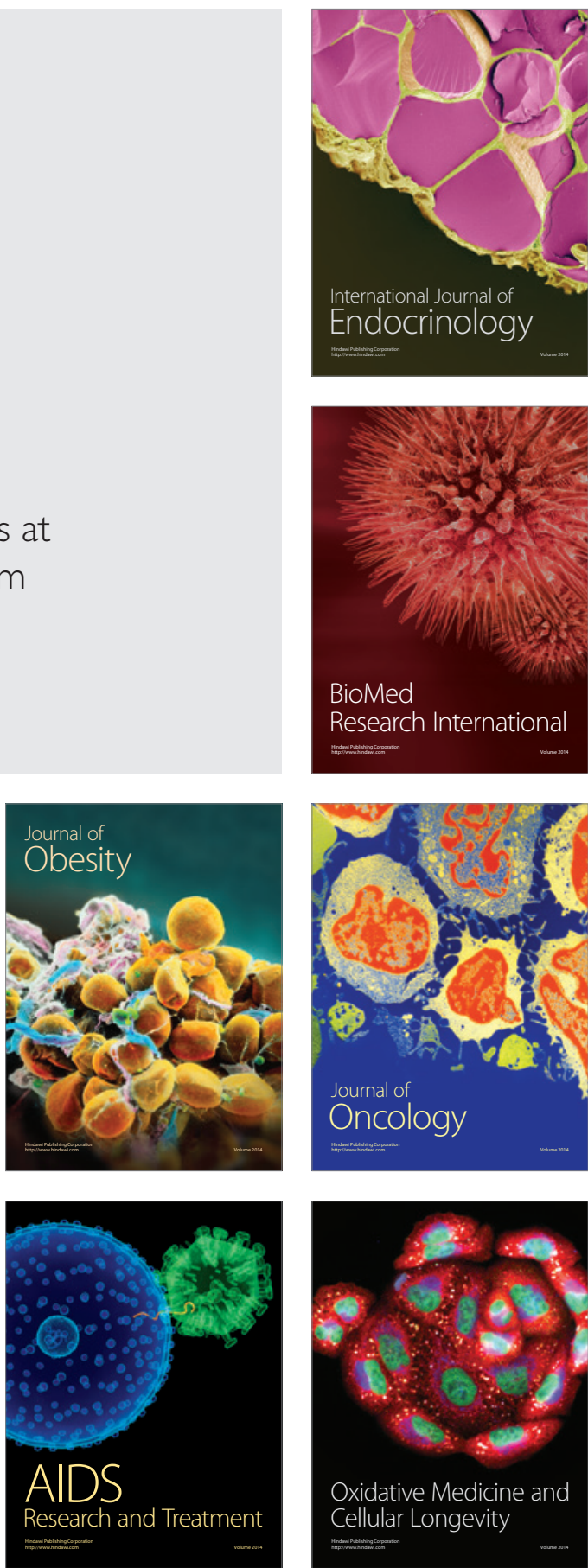